\title{
Geochemistry and petrology of the Búzios Island alkaline massif, SE, Brazil
}

\author{
Geoquímica e petrologia do maciço alcalino da Itha dos Búzios, SE, Brasil \\ Celso de Barros Gomes ${ }^{1 *}$, Francisco Rubens Alves ${ }^{1}$, Rogério Guitarrari Azzone ${ }^{1}$, \\ Gaston Eduardo Enrich Rojas ${ }^{1}$, Excelso Ruberti ${ }^{1}$
}

\begin{abstract}
The Late Cretaceous Búzios Island alkaline massif intrudes Precambrian charnockites and consists dominantly of syenitic rocks that are cut by a large number of dikes, mostly NE-trending, and representing two distinct suites, a felsic one and a mafic-ultramafic one. Alkali feldspar is the most abundant mineral; other constituents are clinopyroxene, commonly replaced by amphibole/ biotite, and opaques. Accessory minerals include occasionally rare phases bearing $\mathrm{Zr}, \mathrm{Ti}, \mathrm{Nb}$ and Rare Earth Elements (REE). The felsic dikes may also have nepheline (sodalite). The mafic-ultramafic suite, in particular the lamprophyres, shows a primary mineral assemblage with olivine, clinopyroxene and amphibole in addition to a groundmass having glassy material and carbonates (ocelli). The Búzios rocks are chemically evolved, mostly of potassic affinity and mainly belong to the miaskitic series. Variation diagrams for major and trace elements show a bimodal distribution, suggesting an origin from different magmatic pulses. The rocks are interpreted as having been derived by fractional crystallization processes from a basanitic parental magma. The $\mathrm{SiO}_{2}$-undersaturated and $\mathrm{SiO}_{2}$-oversaturated associations present in the massif are apparently not linked to a single magmatic source, and in the petrogeny residual system two trends are evident: the first one towards the phonolitic minimum and the second one towards the rhyolitic minimum, possibly pointing to amphibole fractionation.
\end{abstract}

KEYWORDS: Igneous petrology; Alkaline rocks; Geochemistry.
RESUMO: O maciço alcalino da Ilha dos Búzios, do Cretáceo Superior, é intrusivo em charnockitos precambrianos e consiste predominantemente de rochas sieniticas cortadas por grande número de diques, orientados preferencialmente para $N E$, representando duas suites distintas: félsica e máfica-ultramáfica. Feldspato alcalino é o mineral mais abundante; outros constituintes são clinopiroxênio, comumente substituido por anfibólio/biotita, e opacos. Minerais acessórios incluem ocasionalmente fases raras contendo $\mathrm{Zr}, T i, \mathrm{Nb}$ e elementos terras raras (ETR). Os diques félsicos podem possuir também nefelina (sodalita). A suite máfica-ultramáfica, particularmente os lamprófiros, apresenta uma assembleia mineralógica primária com olivina, clinopiroxênio e anfibólio, além de massa fundamental com material vitreo e carbonatos (ocelli). As rochas de Búzios são quimicamente evoluidas, de filiação claramente potássica e pertencem sobretudo à série miaskitica. Diagramas de variação para elementos maiores e traços mostram distribuição bimodal, sugerindo a origem a partir de diferentes pulsos magmáticos. As rochas são interpretadas como derivadas por cristalizaçáa fracionada a partir de magma parental de composição basanítica. As associaçōes insaturadas e supersaturadas em $\mathrm{SiO}_{2}$ presentes no maciço não estão aparentemente ligadas a uma fonte magmática única, sendo evidentes duas tendências distintas no sistema petrogenético residual: a primeira no sentido do mínimo fonolítico, e a segunda no do mínimo riolítico, possivelmente indicando fracionamento de anfibólio.

PALAVRAS-CHAVE: Petrologia ignea; Rochas alcalinas; Geoquimica.

${ }^{1}$ Instituto de Geociências, Universidade de São Paulo - USP, São Paulo (SP), Brasil. E-mail: cgomes@usp.br

*Corresponding author.

Manuscript ID: 20160121. Received: 10/26/2016. Approved: 01/03/2017. 


\section{INTRODUCTION}

Coastal islands composed mainly of alkaline rocks are found along the shoreline of the state of São Paulo, in Southeastern Brazil, forming stocks and a great number of dikes of variable compositions and dimensions. The well-known occurrences are São Sebastiāo (the largest island encompassing three syenitic bodies: São Sebastião, Serraria, and Mirante), Búzios, Vitória, and Monte de Trigo (Fig. 1), all aligned along a NE trend parallel to the regional structure represented by the Santos fault and related tectonically to the Southeastern Brazilian Continental Rifting (Riccomini et al. 2005). These alkaline centers are included in the Serra do Mar Province (cf. Almeida 1983) or, specifically, in the northern sector of the Serra do Mar Province (cf. Riccomini et al. 2005), and were emplaced into the Precambrian crystalline basement (Ribeira belt, 790510 Ma, cf. Heilbron et al. 2008).

Geological information on such alkaline occurrences dates back to the last century — as São Sebastiáo (Freitas 1947; Hennies \& Hasui 1968, 1977; Bellieni et al. 1990; Garda 1995; Lima \& Schorscher 1999), Búzios (Björnberg \& Ellert 1955; Alves 1997), Vitória (Motoki \& Gomes 1984; Motoki 1986; Motoki et al. 1987), and Monte de Trigo (Coutinho \& Melcher 1973) — , but more recently these islands, especiallly Monte de Trigo, have become the subject of systematic works dealing mainly with their mineralogy, geochemistry and petrology, like São Sebastião (Augusto \& Vlach 2004; Enrich et al. 2005), Búzios (Alves \& Gomes 2001), Vitória (Motoki et al. 2015), and Monte de Trigo (Enrich 2005; Enrich et al. 2009, 2016).

$\mathrm{K} /$ Ar determinations on mineral concentrates (biotite and amphibole) and whole rocks allowed Alves (1997) to suggest for the Búzios syenitic rocks an average age of $81.4 \pm 2.6 \mathrm{Ma}$ (Late Cretaceous) and a younger value of $79.0 \pm 2.4 \mathrm{Ma}$ for the associated dikes. The author also reported a $\mathrm{Rb} / \mathrm{Sr}$ isochron (errochron) including various petrographic types of the massif that indicated an age of 78.0 $\pm 2.2 \mathrm{Ma}$, with $\mathrm{R}_{\mathrm{o}}=0.70500$. Several available ages given by different analytical methods for the neighbouring alkaline intrusions range from 90 to $80 \mathrm{Ma}$, lying mostly in the 86-81 Ma interval (Amaral et al. 1967; Sonoki \& Garda 1988; Bellieni et al. 1990; MontesLauar et al. 1995; Alves \& Gomes 2002; Enrich et al. 2005, 2009; Sato et al. 2008). Age values in this range also characterize other alkaline occurrences present in the southern part of the São Paulo state, such as Cananeia (83.6 Ma, Spinelli \& Gomes 2008), Ponte Nova (87.6 Ma, Azzone

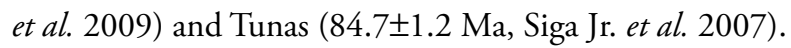

This paper provides a general picture of the alkaline magmatism of Búzios Island, emphasizing the geochemistry and mineral chemistry of the rocks and contributing to a better understanding of the formation and evolution of the alkaline massif.

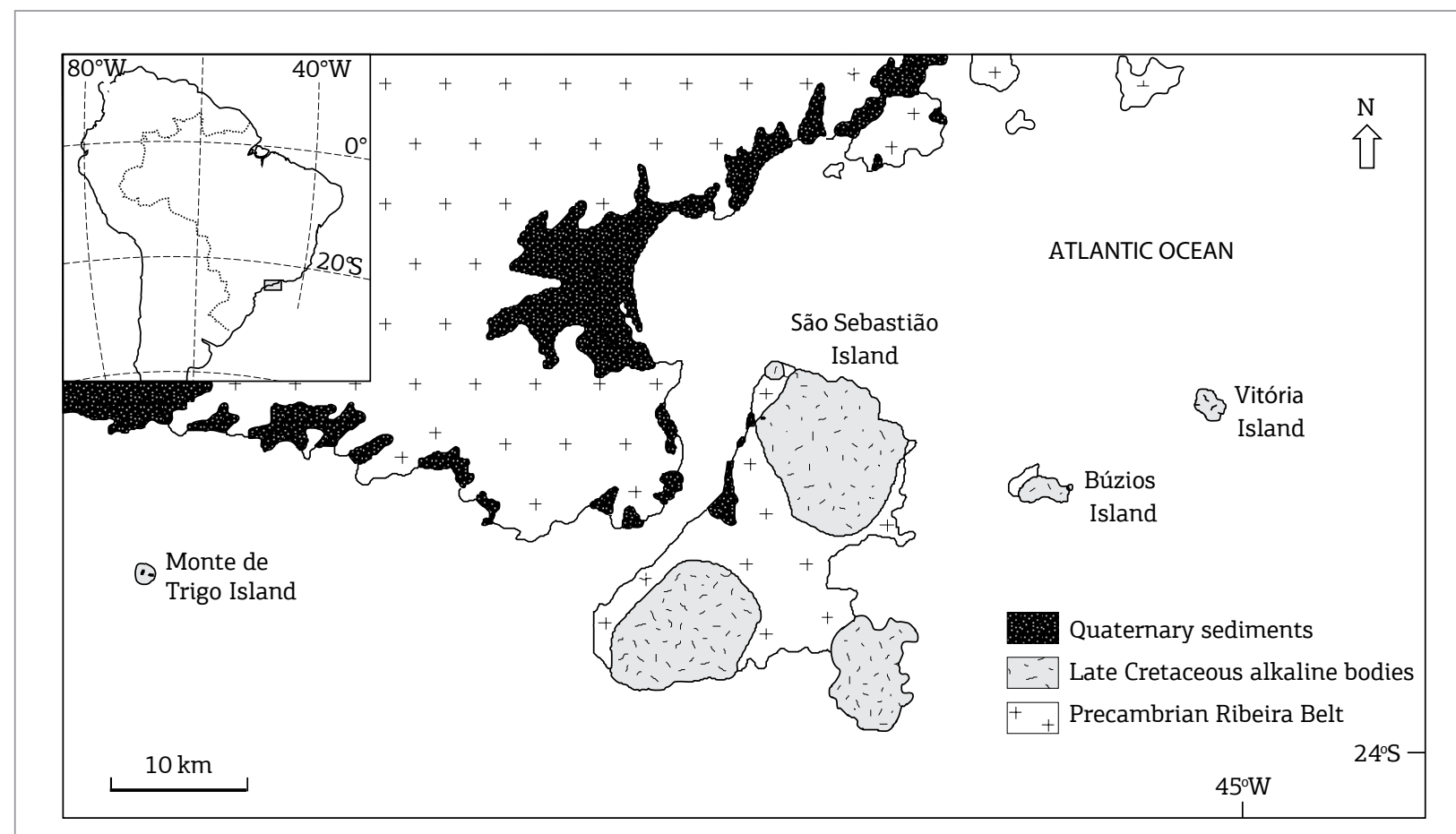

Figure 1. Geological map of the northern sector of the Serra do Mar Province (after Alves and Gomes 2001, simplified). 


\section{GEOLOGICAL ASPECTS}

The Búzios alkaline massif, which includes Búzios Island and a very small nearby island named Somítica, is irregular and extends more than $3 \mathrm{~km} \mathrm{N-S}$ and $5 \mathrm{~km} \mathrm{E-W} \mathrm{(Fig.} \mathrm{2).}$ The main island covers an area of approximately $7.5 \mathrm{~km}^{2}$ and lies approximately $30 \mathrm{~km}$ from the continent. It is composed mostly of syenites totalling more than $90 \%$ of the entire area, with coarse-grained Precambrian charnockites with dark green colour and oriented feldspars occurring as country rocks in its NW and SW sections. Other basement rocks (gneisses and amphibolites) crop out locally as small intercalations and xenoliths or form banded structures.

Dikes are widespread, intruding either country rocks or syenites, and can be assembled into two distinct suites, felsic one and mafic-ultramafic one. They are predominantly NE-trending, subvertical, around 10 centimeters to a few meters wide, and sometimes extend more than 100 meters in length. Cross-cutting bodies with different compositions that form multiple intrusions are also noted. The many dikes seem to indicate the presence of various magmatic stages, although the field relationships involving the different types and the syenitic rocks are not clear.

Xenoliths are usually found in the contact zone between the syenites and country rocks, with the most common type represented by charnockites and mafic lithologies. In addition, quartz-filled, irregular, miarolitic cavities with dimensions of centimeters are present in many places, frequently in association with syenitic rocks.

The syenites and associated microsyenitic rocks can be grouped into the following suites: the first one bears only trace amounts of quartz, and the second one is more enriched in the mineral (up to 5\%). These latter petrographic types occur commonly in the NW and SW parts of the island associated with charnockites. Scarce lithologies having higher quartz content (granophyric varieties) are also recognized. In Le Maitre's (1989) quartz, alkali feldspar, plagioclase, feldspathoid (QAPF) classification diagram, the syenites

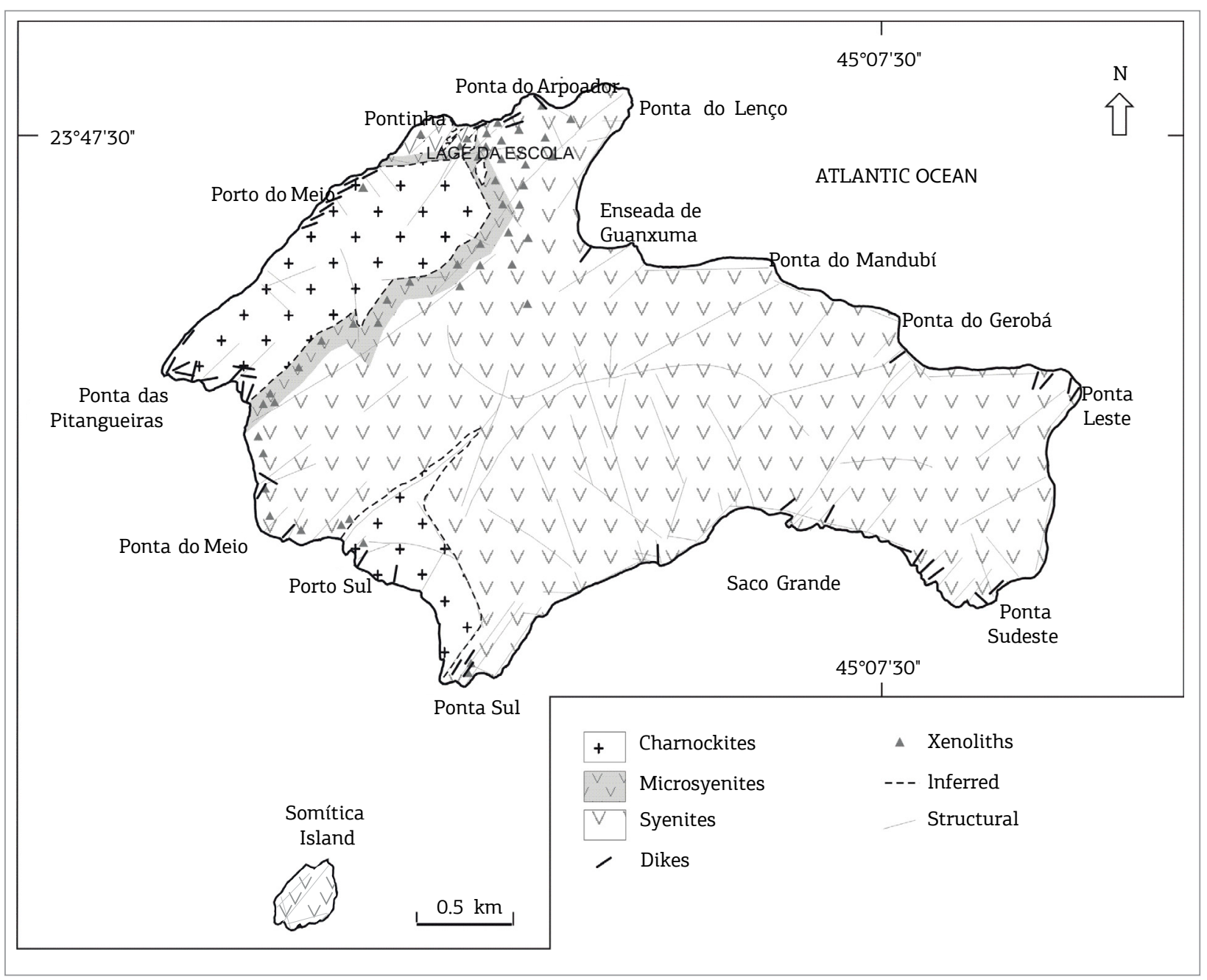

Figure 2. Geological map of the Búzios Island (after Alves 1997, simplified). 
generally plot in the alkali feldspar syenite and quartz-alkali feldspar syenite fields, with a clear prevalence of the former rocks. The syenites are dominantly coarse-grained, with a massive aspect, light to dark gray in color, and equigranular to inequigranular in texture. Fine-grained varieties are also classified as alkali feldspar microsyenites or quartz-alkali feldspar microsyenites. More rarely, they lie in the alkali feldspar (micro) granite field. These rocks show light color and equigranular to seriate texture, are occasionally porphyritic and are of light color; in a few cases, they can be typically aplitic in texture.

Felsic dikes are variable in composition and consist of rocks $\mathrm{SiO}_{2}$-undersaturated (nepheline/sodalite mycrosyenites and sodalite phonolites) to $\mathrm{SiO}_{2}$-saturated (microsyenites and trachytes) and $\mathrm{SiO}_{2}$-oversaturated (rhyolites). The saturated types are especially widespread over the whole island. The $\mathrm{SiO}_{2}$-rich varieties mostly occur intruding the charnockites, whereas the $\mathrm{SiO}_{2}$-poor types commonly have syenites as country rocks. On the other hand, the mafic-ultramafic dikes are represented by alkaline rock types such as alkali basalts, basanites, tephrites, trachybasalts, and lamprophyres (dominantly camptonites following Le Maitre 1989). In rocks of this assemblage, the texture is usually holocrystalline, fine-grained to aphanitic, and microporphyritic to porphyritic; and the color varies from light gray to black. Diabase dikes with tholeiitic affinity predate the alkaline activities and were also found in the island cutting the charnockites and presenting textural re-equilibration probably due to the intrusion of the alkaline magmas.

A detailed and complete mineralogical and petrographic description of the Búzios alkaline rocks is given in Alves (1997), with a more concise version published by Alves and Gomes (2001).

\section{MINERALOGY}

Chemical analyses of feldspars, clinopyroxenes, amphiboles, micas, and opaques and diagrams relating cationic concentrations and ratios of distinct elements in some minerals are listed in Alves (1997) (for the data source and analytical conditions, access the site: http://www.teses.usp. br/teses/disponiveis/44/44135/tde-18092015-174733/ pt-br.php). Analyses of rare minerals (see Table 1) were

Table 1. Representative WDS analyses of Zr-, Ti-, Nb-, and REE-rich silicate minerals of agpaitic dikes from Búzios Island.

\begin{tabular}{|c|c|c|c|c|c|c|}
\hline Mineral & Wöhlerite & Låvenite & Mosandrite & Rosenbuschite & Eudialyte & Astrophyllite \\
\hline Rock-type & $\begin{array}{l}\text { Nepheline } \\
\text { microsyenite }\end{array}$ & Phonolite & Phonolite & $\begin{array}{l}\text { Nepheline } \\
\text { microsyenite }\end{array}$ & Phonolite & Phonolite \\
\hline \multicolumn{7}{|l|}{ wt \% } \\
\hline $\mathrm{SiO}_{2}$ & 29.19 & 28.36 & 29.57 & 31.08 & 47.60 & 33.65 \\
\hline $\mathrm{TiO}_{2}$ & 1.25 & 2.94 & 6.10 & 6.79 & 0.09 & 9.68 \\
\hline $\mathrm{ZrO}_{2}$ & 14.56 & 27.23 & 2.44 & 13.27 & 12.21 & 0.90 \\
\hline $\mathrm{HfO}_{2}$ & 0.21 & 0.29 & n.a. & $<0.11$ & 0.28 & $<0.11$ \\
\hline $\mathrm{Nb}_{2} \mathrm{O}_{5}$ & 13.43 & 5.22 & 3.41 & 2.84 & 2.38 & 1.62 \\
\hline $\mathrm{Al}_{2} \mathrm{O}_{3}$ & $<0.02$ & $<0.02$ & 0.07 & $<0.02$ & 0.30 & 1.36 \\
\hline $\mathrm{Y}_{2} \mathrm{O}_{3}$ & 0.42 & 0.33 & 1.25 & 0.67 & 0.51 & $<0.04$ \\
\hline $\mathrm{La}_{2} \mathrm{O}_{3}$ & $<0.05$ & $<0.05$ & 4.86 & 0.10 & 1.20 & n.a. \\
\hline $\mathrm{Ce}_{2} \mathrm{O}_{3}$ & 0.25 & $<0.09$ & 10.44 & 0.38 & 1.71 & $<0.08$ \\
\hline $\mathrm{Nd}_{2} \mathrm{O}_{3}$ & n.a. & n.a. & 2.55 & 0.23 & 0.34 & n.a. \\
\hline $\mathrm{FeO}$ & 0.95 & 4.55 & $<0.06$ & 0.83 & 5.09 & 26.79 \\
\hline $\mathrm{MnO}$ & 1.39 & 5.66 & 0.09 & 2.12 & 4.97 & 8.28 \\
\hline $\mathrm{MgO}$ & 0.07 & 0.05 & $<0.02$ & 0.05 & $<0.02$ & 0.24 \\
\hline SrO & $<0.04$ & $<0.04$ & $<0.04$ & $<0.04$ & $<0.04$ & $<0.04$ \\
\hline $\mathrm{CaO}$ & 25.91 & 8.09 & 22.16 & 25.91 & 8.17 & 1.56 \\
\hline $\mathrm{Na}_{2} \mathrm{O}$ & 7.40 & 10.93 & 8.57 & 9.34 & 8.11 & 2.21 \\
\hline $\mathrm{K}_{2} \mathrm{O}$ & $<0.02$ & 0.03 & 0.05 & 0.04 & 0.29 & 6.34 \\
\hline $\mathrm{F}$ & 3.29 & 2.97 & 7.02 & 5.04 & 0.46 & 0.84 \\
\hline $\mathrm{Cl}$ & $<0.03$ & $<0.03$ & $<0.03$ & $<0.03$ & 1.33 & $<0.03$ \\
\hline$-\mathrm{O} \approx \mathrm{F}, \mathrm{Cl}$ & 1.39 & 1.25 & 2.96 & 2.12 & 0.49 & 0.35 \\
\hline Sum & 96.92 & 95.40 & 95.61 & 96.56 & 94.53 & 93.11 \\
\hline
\end{tabular}

n.a.: not analyzed 
performed in a Jeol JXA-8600 electron microprobe at the Geoanalítica, at University of Sao Paulo (USP) facility, using an accelerating voltage of $15 \mathrm{kV}$, a beam current of $20 \mathrm{nA}$ and a combination of well-analyzed natural and synthetic standards.

\section{Feldspars}

Alkali feldspar, mainly represented by micro- to mesoperthite of distinct and complex textural patterns, is the most important constituent of the Búzios rocks. The mineral is abundant in all of the lithologies, except for the mafic and lamprophyric rocks, in which it occurs interstitially or within the ocelli as a very pure potassic phase. Alkali feldspar usually shows a low anorthite (An) content and a heterogeneous composition that grades continuously along the orthoclase (Or)-albite $(\mathrm{Ab})$ side of the Or-Ab-An ternary diagram or is grouped mainly at its $\mathrm{Ab}$ corner (Figs. $3 \mathrm{~A}$ and $3 \mathrm{~B}$ ). In dikes, the mineral is found as microcrysts to phenocrysts of either albite or sanidine, or even as exsolution lamellae. Plagioclase is almost restricted to the mafic-ultramafic dikes, forming crystals widely variable in composition $\left(\mathrm{An}_{75-30}\right)$, with the matrix phases generally more enriched in $\mathrm{Ab}$ compared to the larger grains (Fig. 3C).

\section{Clinopyroxenes}

These minerals are present as large crystals in medium- to coarse-grained rocks, as microcrysts to phenocrysts in finegrained varieties, or as groundmass phases in some felsic to mafic-ultramafic dikes. The composition is highly variable,

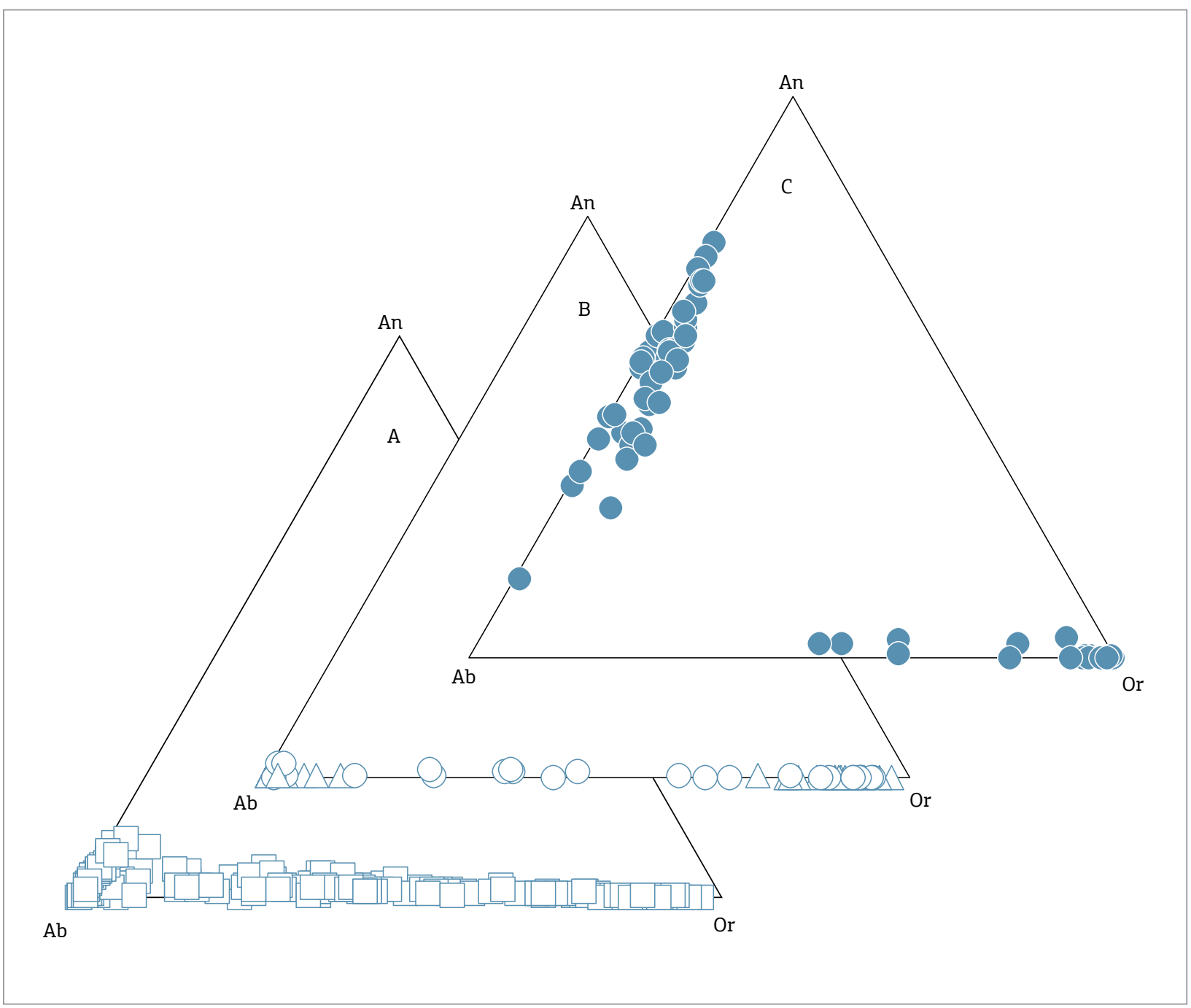

Figure 3. Chemical analyses of Búzios feldspars in the Ab-Or-An diagram (after Alves 1997). Symbols: (A) open square, syenite; (B) open circle, trachyte; open triangle, nepheline (sodalite) microsyenite and phonolite; (C) full circle, mafic-ultramafic rocks. 
ranging from more calcic to calcic-sodic to sodic types in the WEF (wollastonite, entatite, ferrossilite) - Jd (jadeite, $\mathrm{NaAlSi}_{2} \mathrm{O}_{6}$ ) - Ae (aegirine, $\mathrm{NaFe}^{3+} \mathrm{Si}_{2} \mathrm{O}_{6}$ ) (cf. Morimoto et al. 1988) triangular diagram (Fig. 4A). In the classical Wo (wollastonite, $\mathrm{Ca}_{2} \mathrm{Si}_{2} \mathrm{O}_{6}$ ) - En (enstatite, $\mathrm{Mg}_{2} \mathrm{Si}_{2} \mathrm{O}_{6}$ ) Fs (ferrossilite, $\mathrm{Fe}_{2} \mathrm{Si}_{2} \mathrm{O}_{6}$ ) diagram (Fig. 4B), they are represented exclusively by diopside in mafic-ultramafic dikes and by diopside-hedenbergite grading to aegirine-augite in mostly syenitic rocks. An aegirinic composition characterizes the felsic dikes (Fig. 4A). Zoning is a common feature of the clinopyroxenes, as indicated by chemical changes and
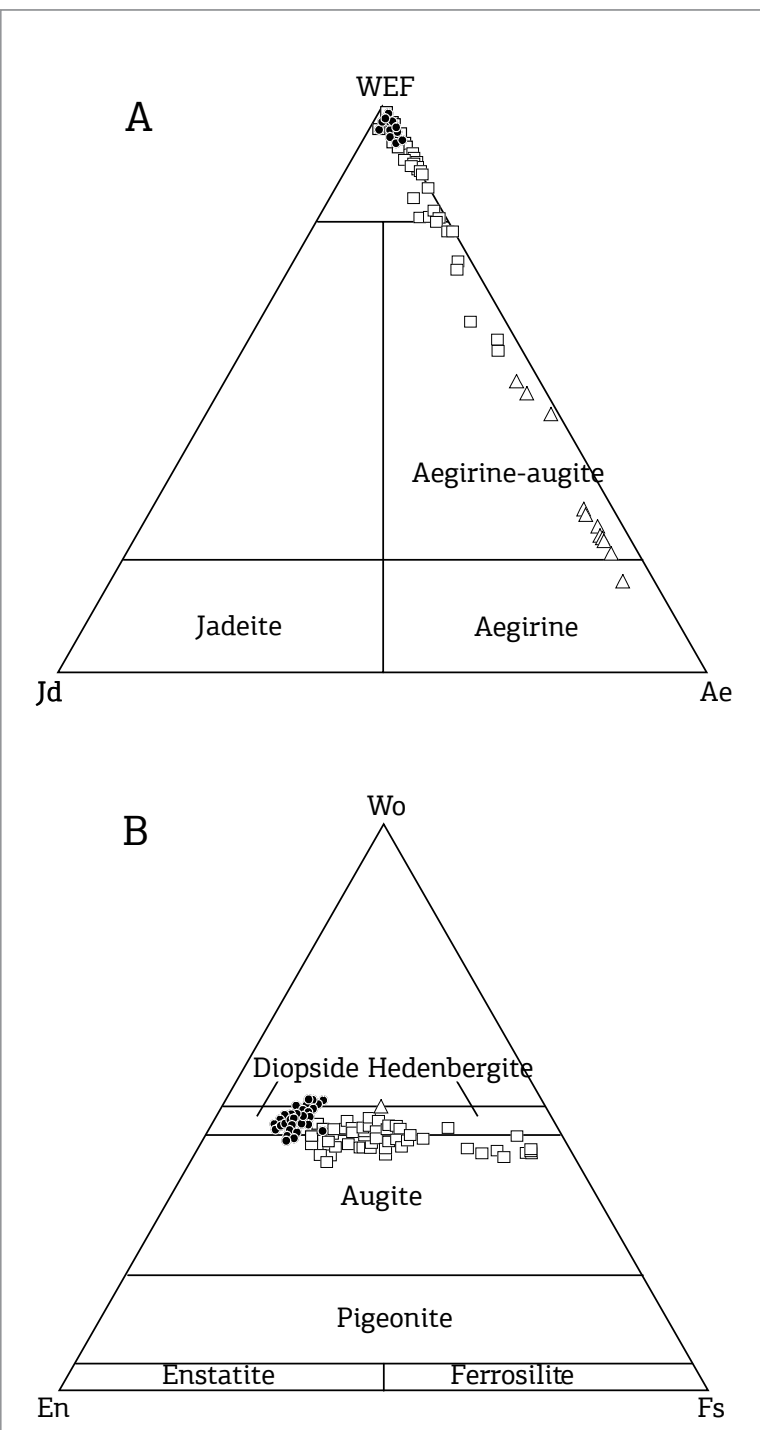

Figure 4. Chemical analyses of Búzios clinopyroxenes (A) in the WEF-Jd-Ae diagram of Morimoto et al. (1988) and (B) in the classical Wo-En-Fs system (after Alves 1997). Symbols: (A) open square, syenite; (B) open circle, trachyte; open triangle, nepheline (sodalite) microsyenite and phonolite; (C) full circle, mafic-ultramafic rocks. variable pleochroism. A decrease in $\mathrm{Mg}$ and a concomitant increase in $\mathrm{Fe}$ and $\mathrm{Na}$ contents is noticed from cores to rims of crystals. This negative correlation is also a characteristic feature of clinopyroxenes from the three Búzios rock suites, whereas a negative correlation between $\mathrm{Mg}$ and $\mathrm{Ti}$ is particularly common in minerals from the mafic-ultramafic suite (Alves 1997). On the whole, these chemical variations reflect the transition of clinopyroxenes of diopsidic composition to minerals more enriched in the acmite molecule. Regarding the pleochroism, a lighter green color is a common feature of the nuclei of zoned crystals, whereas a darker green is typical of its margins.

Figure 5 shows the crystallization trends of clinopyroxenes from Búzios and other alkaline occurrences from Southeastern Brazil. Two distinct trends for the Búzios minerals are distinguished. The first trend exhibits a continuous increase in the $\mathrm{Fe}^{*}\left(\mathrm{Fe}^{2+}+\mathrm{Mn}+\mathrm{Fe}^{3+}-\mathrm{Na}\right)$ concentration, with $\mathrm{Na}$ almost constant during the decrease of $\mathrm{Mg}$ content, followed by a $\mathrm{Na}$ enrichment in low $\mathrm{Mg}$ - clinopyroxenes; it is commonly associated with amphibole-bearing rocks (Fig. 5A). The second trend, represented by the rims of zoned crystals from syenitic rocks and by samples from felsic dikes, displays a strong enrichment in $\mathrm{Na}$ and minor variations in the $\mathrm{Mg} / \mathrm{Fe}^{*}$ ratio; it is usually associated with amphibole-free rocks (Fig. 5B). The first trend presents similarities with those of minerals from the São Sebastião Island (Bellieni et al. 1990), the Morro Redondo (Brotzu et al. 1989) and the Morro de São João (Brotzu et al. 2007) alkaline intrusions (Fig. 5C). On the other hand, the second trend approaches the pattern displayed by rocks from the Mantiqueira Mountain complexes of Passa Quatro (Brotzu et al. 1992) and Itatiaia (Brotzu et al. 1997), as also shown in Figure 5C. Variable oxidizing conditions during crystallization could account for the difference in $\mathrm{Fe}^{2+}$ enrichment relative to $\mathrm{Fe}^{3+}$ and $\mathrm{Na}$ enrichment in clinopyroxenes (Marks et al. 2008).

\section{Amphiboles}

These minerals are widespread in Búzios rocks and usually formed after the breakdown of clinopyroxenes. In some samples, particularly of mafic and lamprophyric dikes, they constitute a primary phase and represent the principal mafic mineral in these rocks. Generally, the amphiboles are joined by biotite that occurs along the borders of their crystals or occupies the cleavage planes. The evolution of these minerals is similar to that of the clinopyroxenes, grading in syenitic rocks from more magnesian towards more ironrich compositions, with the amphiboles mostly classified as $\mathrm{Mg}$ - and Fe-hornblende, respectively (cf. Leake 1997). The enrichment in $\mathrm{Fe}$ is also accompanied by a progressive increase in $\mathrm{Na}$ content. In a few samples, the amphiboles are 
Fe-barroisite, edenite or hastingsite in composition. In felsic dikes, the mineral corresponds to katophorite (highest Fe contents) and riebeckite in more $\mathrm{Na}$-rich varieties, whereas in mafic-ultramafic ones, it falls dominantly into the kaesurtite field and contains high $\mathrm{Ti}$ and $\mathrm{Al}$ concentrations.

\section{Micas}

Micas are present in all lithologies of the massif, but less frequently in felsic dikes. Except in the lamprophyric rocks, the minerals are of secondary origin and variable color and occur closely associated with clinopyroxenes and amphiboles. The chemical composition shows high $\mathrm{Ti}$ and wide variations in $\mathrm{Al}$ contents and $\mathrm{Fe} / \mathrm{Fe}+\mathrm{Mg}$ ratios, although in most of the cases the minerals may be called biotite. The more magnesian varieties are related to mafic-ultramafic dikes and contain higher $\mathrm{Al}^{\mathrm{IV}}$ and Ti concentrations, approaching the eastonite-siderophylite series (Fig. 6). In general, Si and $\mathrm{Al}^{\mathrm{IV}}$ cationic proportions are insufficient to fill the tetrahedral site, with the position being completed by $\mathrm{Fe}^{3+}$ or $\mathrm{Ti}^{4+}$, as it has been noted in several alkaline occurrences from Southeastern Brazil (see, for instance, Morbidelli et al. 1995).

\section{Quartz}

This mineral is present in variable amounts as individual crystals or as interstitial aggregates. $\mathrm{SiO}_{2}$-oversaturated syenitic rocks have amphibole as the main mafic mineral and quartz in association with alkali feldspar, forming a typical granophyric texture.

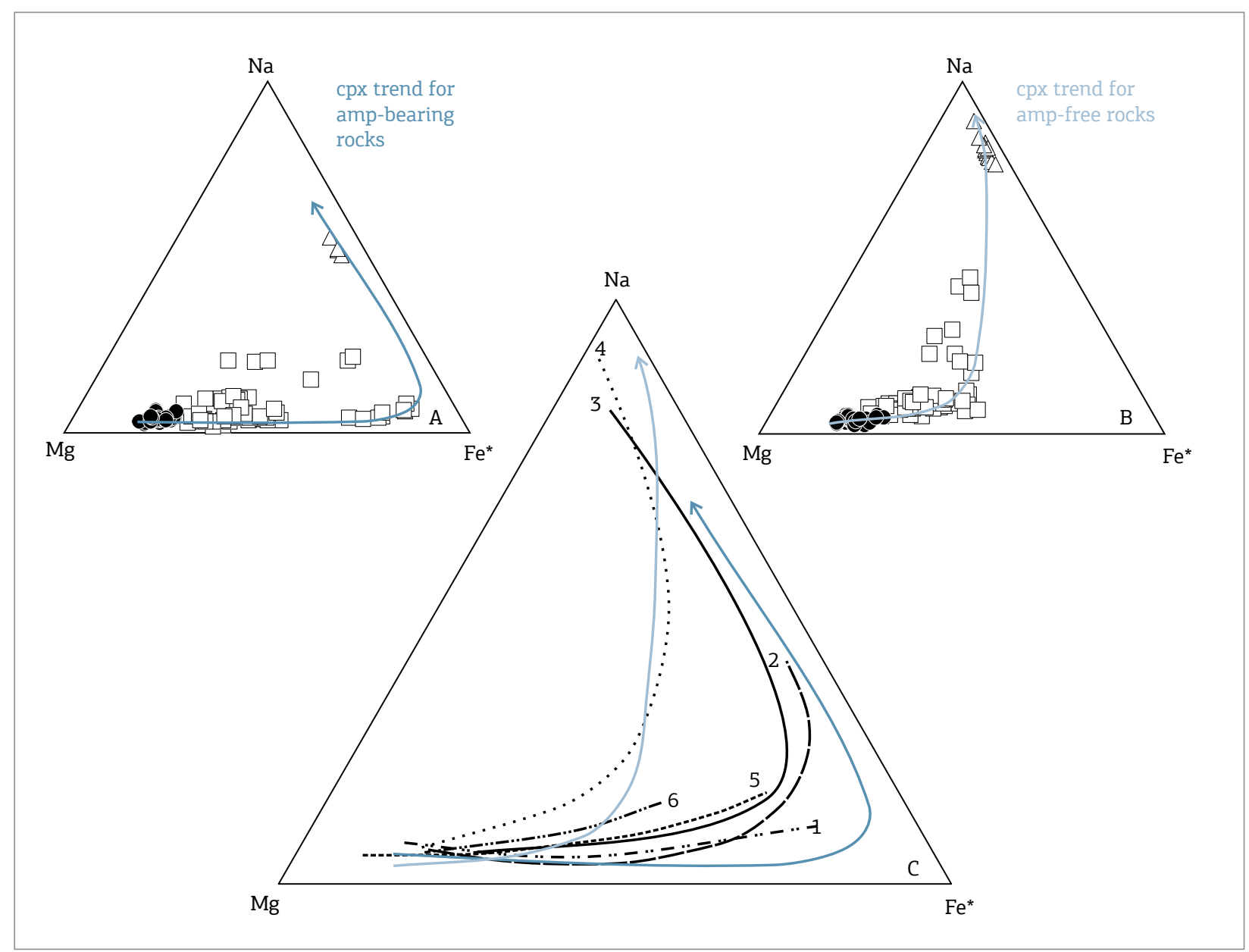

Figure 5. (A) Cristallization trend of Búzios clinopyroxenes for amphibole-free lithotypes. (B) Cristallization trend of Búzios clinopyroxenes for amphibole-bearing lithotypes. Symbols: (A) open square, syenite; (B) open circle, trachyte; open triangle, nepheline (sodalite) microsyenite and phonolite; (C) full circle, mafic-ultramafic rocks. (C) Comparison of the different Búzios clinopyroxene trends with the main evolutionary trends for clinopyroxenes of alkaline complexes from southeastern Brazil. $\mathrm{Fe}^{*}=\left(\mathrm{Fe}^{2+}+\mathrm{Mn}+\mathrm{Fe}^{3+}-\mathrm{Na}\right)$. References: 1. São Sebastião Island (Bellieni et al. 1990); 2. Vitória Island (Motoki 1986); 3. Monte de Trigo Island (Enrich 2005); 4 . Passa Quatro (Brotzu et al. 1992) and Itatiaia (Brotzu et al. 1997); 5. Morro Redondo (Brotzu et al. 1989); 6. Morro de São João (Brotzu et al. 2007). Dark blue line, clinopyroxene trend for Búzios amphibole-bearing rocks; light blue line: clinopyroxene trend for Búzios amphibole-free rocks. 


\section{Feldspathoids}

This mineral group contains nepheline as the most abundant constituent, but sodalite and analcite are also recognized. The latter phase is present in the groundmass or as ocelli in lamprophyric rocks, with the mineral occurring in close contact with glass and secondary minerals (carbonates and zeolites). Cancrinite is the main alteration product of nepheline and occupies the boundaries of its crystals or occurs concentrated along its fractures. Alves (1997) reported nepheline crystals with minor quartz $\left(\mathrm{Q}_{6-7}\right)$ and main nepheline $\left(\mathrm{Ne}_{73-74}\right)$ endmembers, indicating equilibrium temperature higher than $775^{\circ} \mathrm{C}$ for the mineral (Hamilton 1961).

\section{Olivines}

Olivines are scarce and almost restricted to the lamprophyric rocks, forming megacrystals or aggregates in association with clinopyroxene, plagioclase, phlogopite, and opaques. The few data available in Alves (1997) point to a composition in the crysolite field (Forsterite: 76-84 mol\%) and $\mathrm{CaO}$ content lower than $0.38 \mathrm{wt} \%$.

\section{Fe-Ti oxide minerals}

These minerals are represented by magnetite that is highly variable in $\mathrm{TiO}_{2}$ (syenitic rocks, $0.40-7.78 \mathrm{wt} \%$; mafic-ultramafic dikes, 17.05-24.25 wt\%) and found as isolated grains or coexisting with ilmenite lamellae $\left(\mathrm{TiO}_{2}\right.$ in syenitic rocks, 44.05-52.23 wt\%; mafic dikes, 47.37$50.13 \mathrm{wt} \%$ ) (Alves 1997). Magnetite is widespread in Búzios lithotypes, whereas ilmenite occurs more frequently

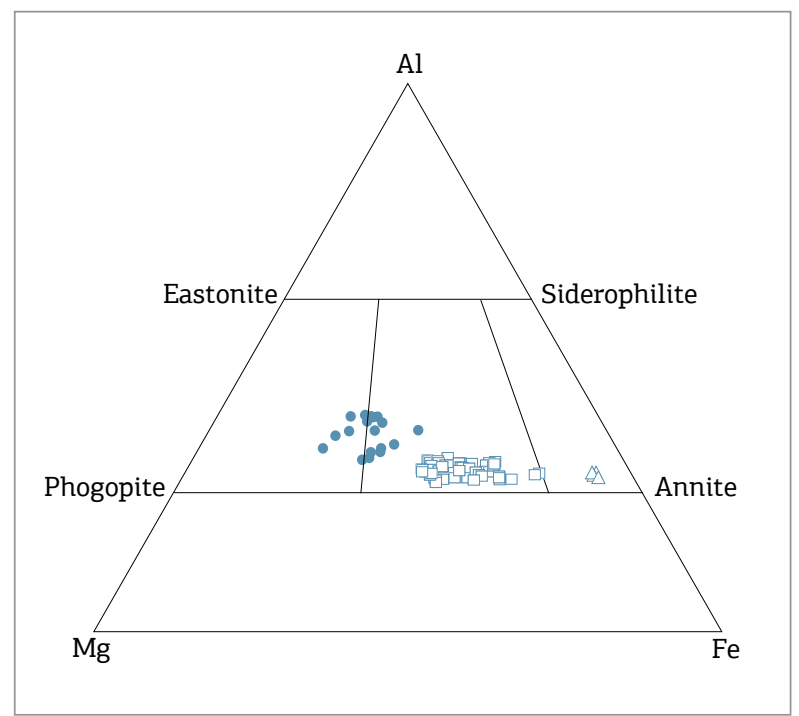

Figure 6. Chemical analyses of Búzios micas in the AlMg-Fe diagram (after Alves 1997). Symbols: (A) open square, syenite; (B) open circle, trachyte; open triangle, nepheline (sodalite) microsyenite and phonolite; (C) full circle, mafic-ultramafic rocks. in syenitic rocks. Temperature calculations by the author using Buddington and Lindsley's (1964) geothermometry suggested values between 580 and $680^{\circ} \mathrm{C}$ and $-\log \mathrm{fO}_{2}$ -18-21 for the syenites; for the mafic dikes, the results are between 870 and $960^{\circ} \mathrm{C}$ and $-\log \mathrm{fO}_{2} \sim 11-13$.

\section{Accessory minerals}

The main accessory minerals are titanite, apatite, zircon, allanite and fluorite. Additionaly, an assemblage of mostly silicate minerals bearing $\mathrm{Zr}, \mathrm{Ti}, \mathrm{Nb}$, and Rare Earth Elements (REE) is identified in association with nepheline (sodalite) microsyenite and phonolite dikes of agpaitic affinity as indicated in Table 1. The whole set of minerals includes låvenite, mosandrite, rosenbuschite and wöhlerite, which are $\mathrm{Na}$-, $\mathrm{Ca}$ - and $\mathrm{F}$-rich sorosilicates with variable amounts of $\mathrm{Zr}, \mathrm{Nb}$, Ti and REE (e.g., Merlino \& Perchiazzi 1988; Christiansen et al. 2003; Bellezza et al. 2009); eudialyte, a $\mathrm{Zr}$-, Fe-, Mn-, Ca-, Na- and Cl-rich cyclosilicate (e.g., Johnsen et al. 2003; Schilling et al. 2011); and astrophyllite, a Ti-, Fe-, Mn- and K-rich heterophyllosilicate (e.g., Piilonen et al. 2003). Other rare accessory to post-magmatic minerals of the felsic dikes are britholite-(Ce), aenigmatite, pyrochlore, fergusonite- $(\mathrm{Y})$, synchysite-(Ce) and bastnäsite-(Ce). Several of them are also typical of similar rocks from the nearby alkaline massif of Monte de Trigo Island (Enrich 2005; Enrich et al., 2016).

\section{GEOCHEMISTRY}

The chemical analyses of the Búzios rocks are taken after Alves (1997) (for the data source, access the site: http://www.teses.usp.br/teses/disponiveis/44/44135/tde18092015-174733/pt-br.php) and plotted in the Totalalkali-silica (TAS) classification diagram (cf. Le Maitre 1989; Fig. 7). Two rock assemblages are easily distinguished, with the first group composed of lithologies more enriched in $\mathrm{SiO}_{2}$ (syenites and felsic dikes) and the second one consisting of less enriched types (mafic-ultramafic dikes), including basic to ultrabasic rocks. The first set can also be divided into syenites to nepheline (sodalite) syenites (trachytes to phonolites) and alkaline granites (rhyolites), the latter lithotypes showing chemical similarities with the basement charnockites. A potassic affinity is indicated for mostly rocks in Middlemost's (1975) $\mathrm{K}_{2} \mathrm{O}$ vs. $\mathrm{Na}_{2} \mathrm{O}$ diagram (Fig. 8), with the exceptions corresponding to several more sodic samples of both felsic and mafic-ultramafic dikes. A bimodal pattern also characterizes the alkalis distribution for syenitic and mafic-ultramafic rocks, with the latter lithologies generally less enriched in $\mathrm{K}_{2} \mathrm{O}$ and $\mathrm{Na}_{2} \mathrm{O}$ in relation to the syenites. 
Based on values for the agpaitic index (A.I. $=\mathrm{Na}_{2} \mathrm{O}+\mathrm{K}_{2} \mathrm{O}$ / $\mathrm{Al}_{2} \mathrm{O}_{3}$, molar ratio), most of the Búzios lithologies are classified as belonging to the miaskitic series. However, some nepheline syenites and especially peralkaline phonolites exhibit typical agpaitic features (cf. Sörensen 1960), as suggested by chemical evidences (A.I.>1.0) and the presence of exotic mineral phases bearing large-ion lithophile element (LILE), high field strength elements (HFSE) and REE (Enrich et al. 2007a,b).

Variation diagrams (Figs. 9 to 10) for major and trace elements against $\mathrm{Mg} \#\left[\mathrm{MgO}_{\text {mol. }} /\left(\mathrm{MgO}_{\text {mol. }}+\mathrm{FeO}_{\text {Tmol. }}\right) * 100\right]$ show again the bimodal distribution of the elements and the existence of well-defined negative correlations for $\mathrm{SiO}_{2}, \mathrm{Na}_{2} \mathrm{O}, \mathrm{Rb}, \mathrm{Nb}, \mathrm{Zr}, \mathrm{La}, \mathrm{Ce}$, and $\mathrm{Nd}$, and positive ones for $\mathrm{TiO}_{2}, \mathrm{FeO}_{\mathrm{T}}, \mathrm{MgO}, \mathrm{CaO}, \mathrm{P}_{2} \mathrm{O}_{5}, \mathrm{Cr}, \mathrm{Ni}$, $\mathrm{Ba}$, and $\mathrm{Sr}$.

The distribution of incompatible elements normalized to the primitive mantle (cf. McDonough and Sun 1995) for the Búzios rocks is displayed in Figure 11. Positive anomalies are indicated for $\mathrm{Nb}, \mathrm{La}-\mathrm{Ce}, \mathrm{Nd}$, and $\mathrm{Zr}$, and pronounced negative spikes occur for $\mathrm{Ba}, \mathrm{Sr}$, and Ti. The positive anomaly for $\mathrm{Ba}$ and the negative one for $\mathrm{Zr}$ also characterize the mafic dikes, and the felsic dikes both undersaturated and supersaturated in silica show approximately the same behavior. On the whole, these patterns are very similar to those described in other alkaline rocks from Southeastern Brazil,

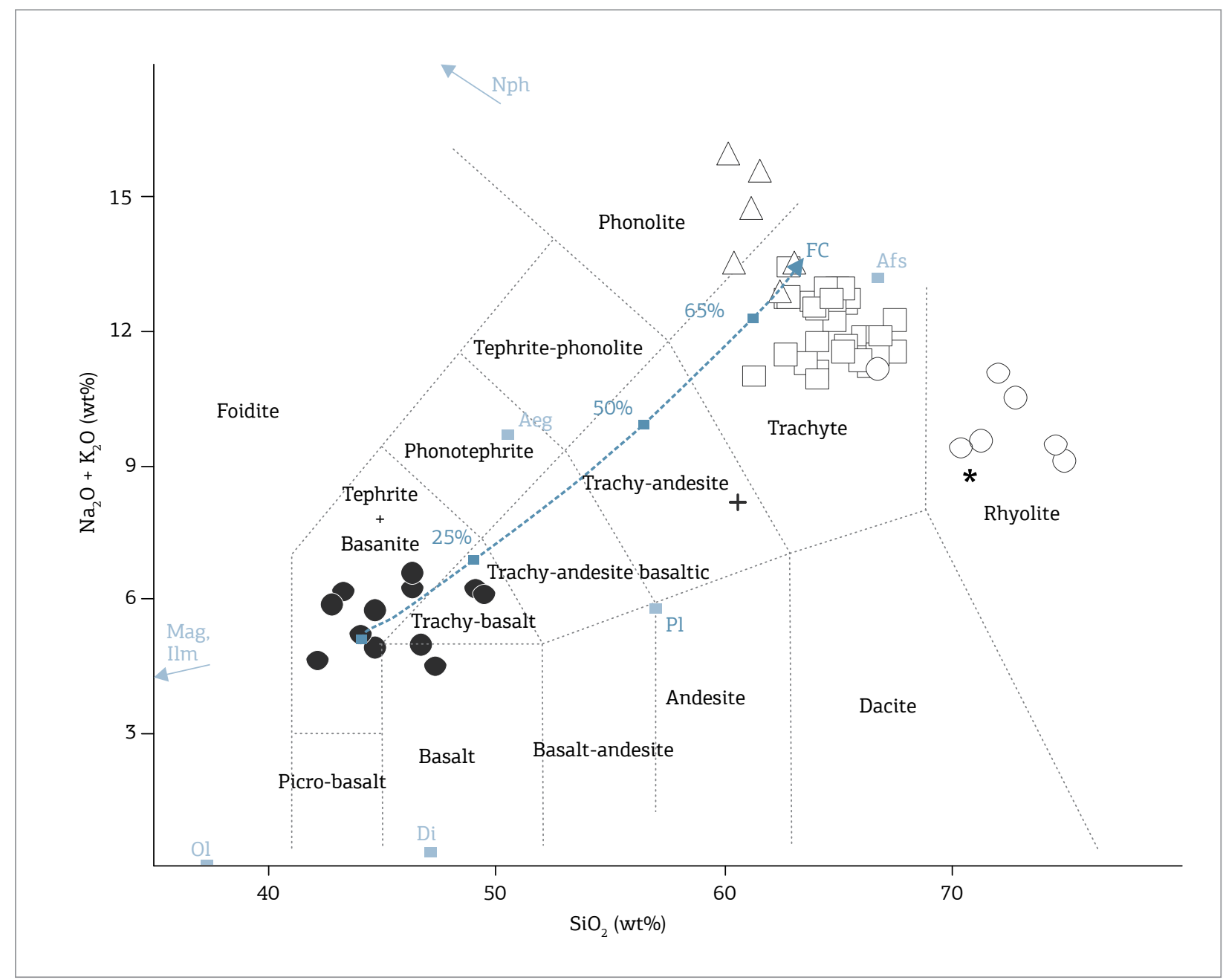

Figure 7. TAS $\left(\mathrm{Na}_{2} \mathrm{O}+\mathrm{K}_{2} \mathrm{O}\right.$ vs. $\mathrm{SiO}_{2}$, in wt\%) diagram (cf. Le Maitre 1989) for the Búzios rocks (after Alves 1997). Symbols: open square, syenite; open circle, trachyte and rhyolite dikes; open triangle, nepheline (sodalite) microsyenite and phonolite dikes; full circle, mafic-ultramafic dikes; cross, mangerite host rock; asterisk, average composition of charnockitic rocks from the Ubatuba area (cf. Neumann 1993). Dark blue dashed line: models of fractional crystallization performed using the MELTS algorithm for initial liquid compositions calculated based on the basanite 326a compositions. The numerals on these lines refer to the percentage of fractionation of solid phases of the system. The conditions inferred for those models are $T_{\text {initial }} \sim 1200^{\circ} \mathrm{C}, \mathrm{P}=1 \mathrm{kbar}, \mathrm{fO}_{2}=\mathrm{QFM}$. The data were recalculated on an anhydrous basis in all diagrams. Mineral poles based on average compositions from Alves (1997). 
particularly the major syenitic occurrences from the Serra do Mar Province (Enrich et al. 2005).

\section{PETROLOGY}

The plutonic and hypabyssal syenitic rocks from Búzios are highly evolved as judged by their $\mathrm{Mg \#}(<0.38)$ and very low $\mathrm{Cr}$ and $\mathrm{Ni}$ contents ( $<11$ and $<21 \mathrm{ppm}$, respectively). Even the mafic-ultramafic dikes are evolved rocks $(\mathrm{Mg} \#<0.65$, $\mathrm{Ni}<235$ ppm).

The bimodal alkaline magmatism found in the Buzios Island massif, with syenitic and felsic fine-grained rocks prevailing over mafic-ultramafic lithologies, is probably linked to fractional crystallization processes from parental basic alkaline magmas. Fractional crystallization from a parental magma of basanitic composition has been proposed as the main evolution process for Early (Juquiá, Beccaluva et al. 1992; Ponte Nova, Azzone et al. 2016) and Late (Lages, Traversa et al. 1996; Monte de Trigo Island, Enrich 2005; Morro Redondo, Brotzu et al. 1989; Passa Quatro, Brotzu et al. 1992; Piratini, Barbieri et al. 1987; São Sebastião Island, Bellieni et al. 1990) alkaline occurrences from Southern Brazil.

The MELTS thermodynamic models of fractional crystallization (Ghiorso \& Sack 1995; Asimow \& Ghiorso 1998) were applied to evaluate the possible relationships of basanite dikes and the syenitic rocks from the Búzios

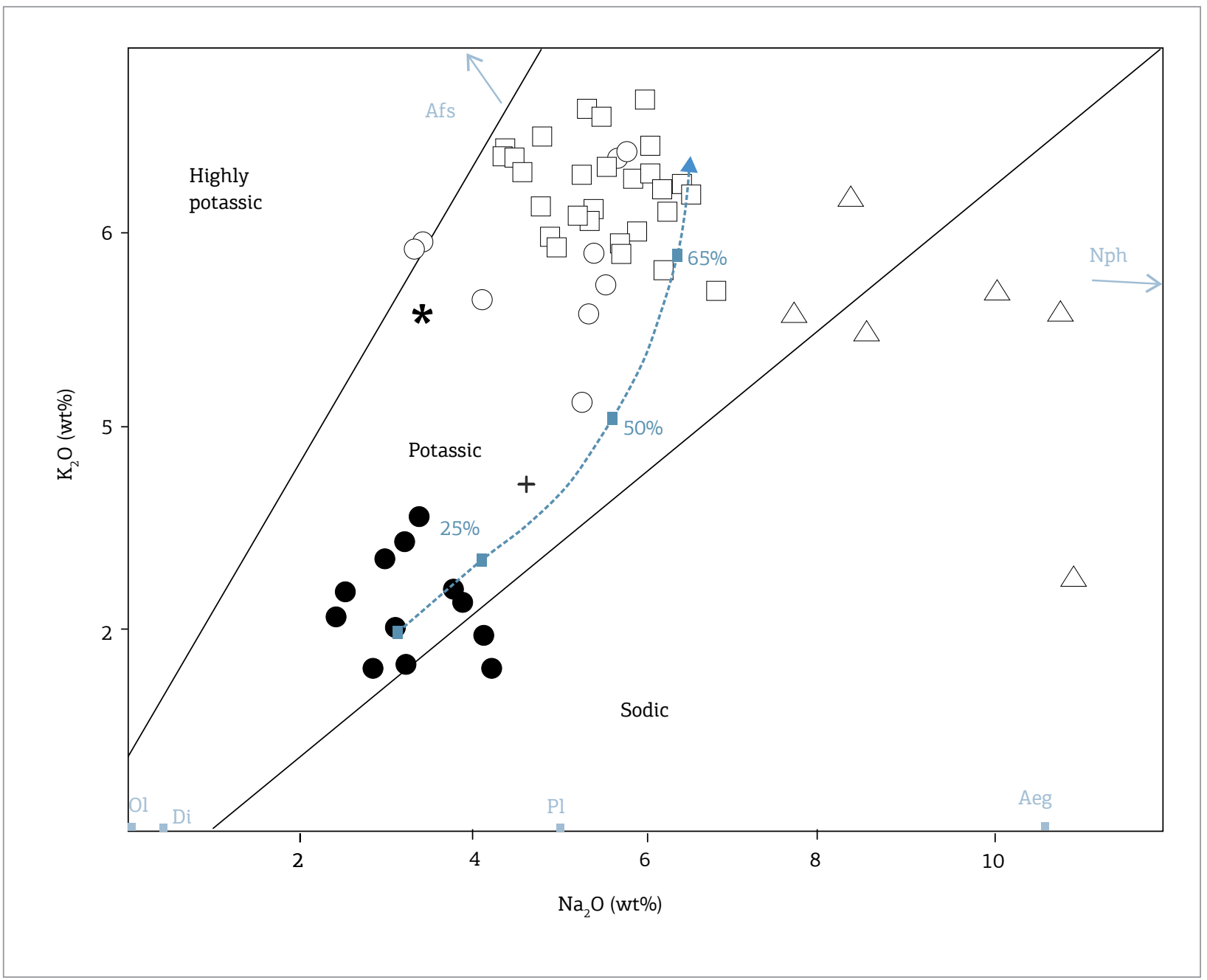

Figure 8. Búzios rocks in the $\mathrm{K}_{2} \mathrm{O}$ vs. $\mathrm{Na}_{2} \mathrm{O}$ Middlemost's (1975) diagram (after Alves 1997). Symbols: open square, syenite; open circle, trachyte and rhyolite dikes; open triangle, nepheline (sodalite) microsyenite and phonolite dikes; full circle, mafic-ultramafic dikes; cross, mangerite host rock; asterisk, average composition of charnockitic rocks from the Ubatuba area (cf. Neumann 1993). Dark blue dashed line: models of fractional crystallization performed using the MELTS algorithm for initial liquid compositions calculated based on the basanite 326a compositions. The numerals on these lines refer to the percentage of fractionation of solid phases of the system. Mineral poles based on average compositions from Alves (1997). 

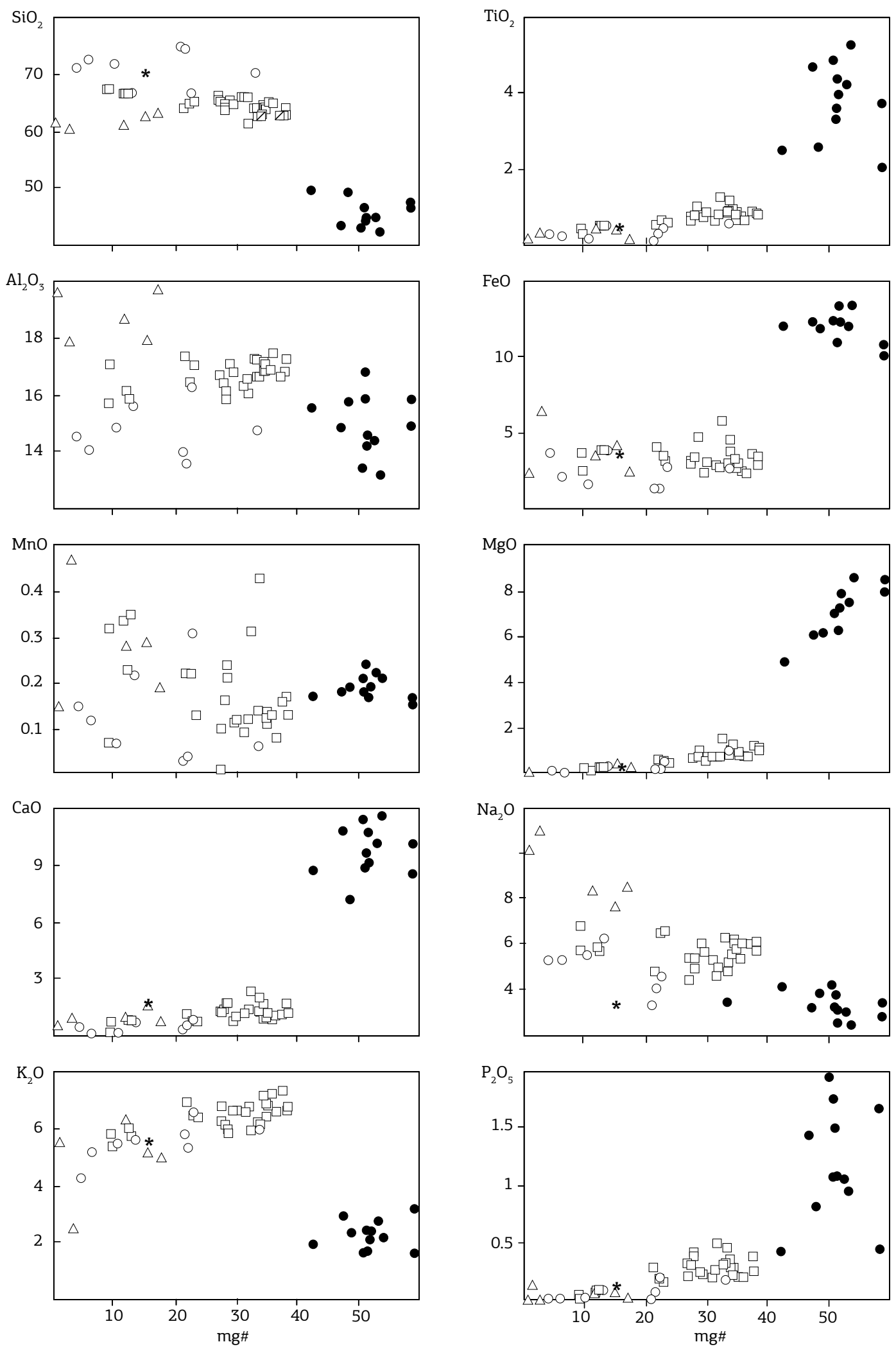

Figure 9. Variation diagrams of major elements against Mg\# for the Búzios rocks (after Alves 1997). Symbols: open square, syenite; open circle, trachyte and rhyolite dikes; open triangle, nepheline (sodalite) microsyenite and phonolite dikes; full circle, mafic-ultramafic dikes; cross, mangerite host rock; asterisk, average composition of charnockitic rocks from the Ubatuba area (cf. Neumann 1993). 

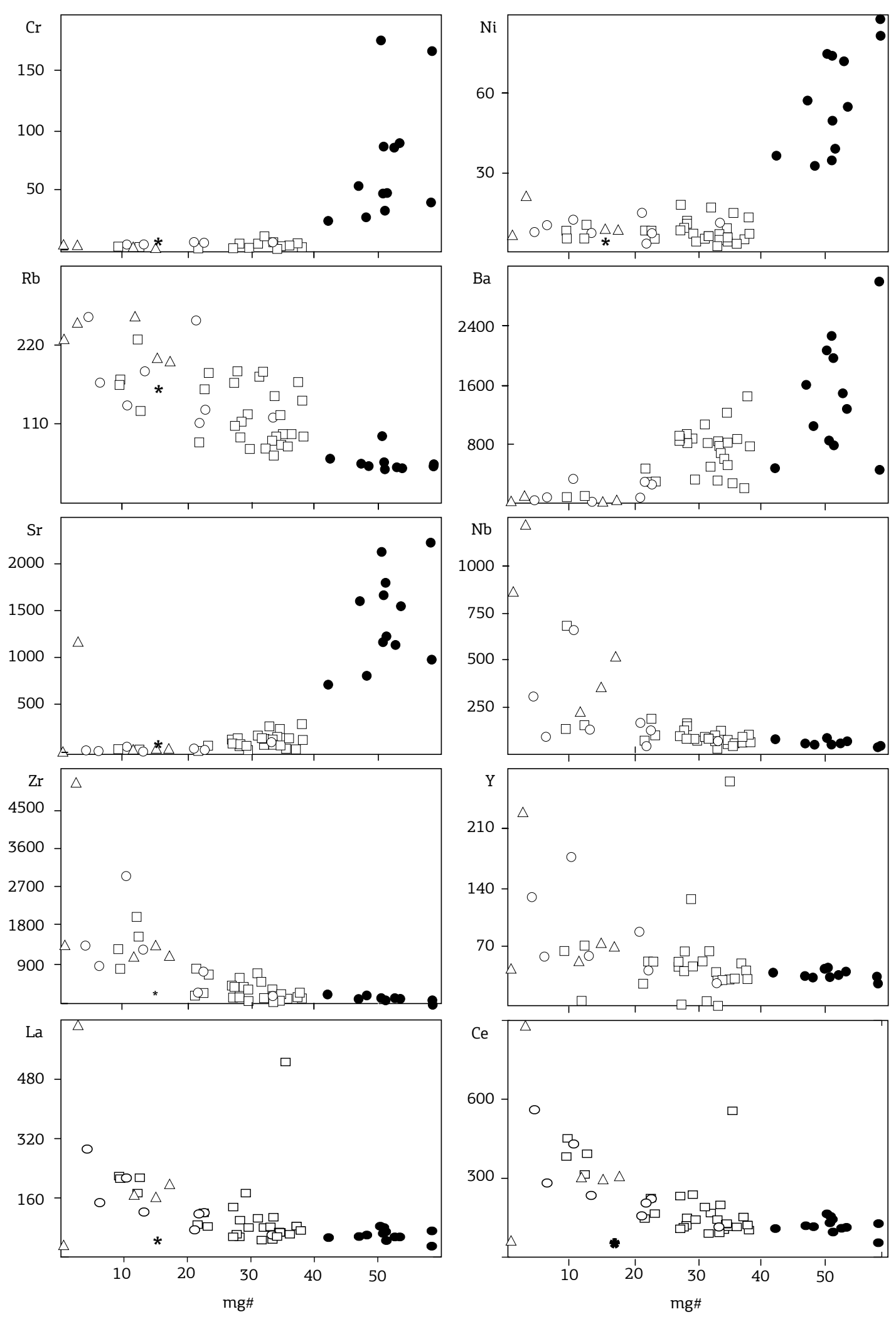

Figure 10. Variation diagrams of trace elements against Mg\# for the Búzios rocks (after Alves 1997). Symbols: open square, syenite; open circle, trachyte and rhyolite dikes; open triangle, nepheline (sodalite) microsyenite and phonolite dikes; full circle, mafic-ultramafic dikes; cross, mangerite host rock; asterisk, average composition of charnockitic rocks from the Ubatuba area (cf. Neumann 1993). 
Island massif (Table 2). These models also indicate the evolutionary trends of the assumed basanite parental melt and the crystallization sequences. The initial composition selected for the models corresponds to that of dike 326a, which is thought to represent a primitive non-cumulus liquid in the intrusion. Although other dikes show a more primitive composition, they are considered to represent a melt bearing an important volume of megacrysts, which could be assigned as antecrysts (Menezes et al. 2015); hence, they are not a good indication of the parental magma composition. The initial $\mathrm{T}\left(-1200-1150^{\circ} \mathrm{C}\right)$ of the assumed parental magma was estimated based on the pyroxene saturation thermometer (Putirka 2008). A low-pressure condition ( $\mathrm{P}=1 \mathrm{kbar})$ was also indicated for most Búzios rocks, as suggested by the $\mathrm{Al}^{\mathrm{VI}}$ contents (usually $<0.1$ a.f.u.) and the calculated cell volumes (VCell $>440 \AA^{3}$, following Nimis, 1995) of the clinopyroxenes. The $\mathrm{fO}_{2}$ buffer fixed for these models was the QFM, compatible with petrographic observations and similar to the one adopted by Trumbull et al. (2003) and Menezes et al. (2015). Low levels of $\mathrm{H}_{2} \mathrm{O}(1.0 \mathrm{wt} \%)$ and $\mathrm{CO}_{2}(0.2 \mathrm{wt} \%)$ were assumed based on petrographic evidences.

The early-crystallized minerals in the applied MELTS models are olivine, spinel and clinopyroxene, whereas apatite and plagioclase represent other fractionated phases.
The trend of the modelled liquid indicates a progressive decrease in the amounts of $\mathrm{MgO}, \mathrm{TiO}_{2}$ and $\mathrm{CaO}$ and, subordinately, an increase in concentrations of $\mathrm{SiO}_{2}, \mathrm{Al}_{2} \mathrm{O}_{3}$ and alkalis $\left(\mathrm{K}_{2} \mathrm{O}\right.$ and $\mathrm{Na}_{2} \mathrm{O}$; Figs. 7 and 8). To reach a syenite composition starting from the basanite would require the fractionation of $-7 \mathrm{wt} \%$ olivine, $-24 \mathrm{wt} \%$ clinopyroxene, $-22 \mathrm{wt} \%$ plagioclase, $-13 \mathrm{wt} \%$ spinel, and $-3 \mathrm{wt} \%$ apatite ( $-65 \%$ fractionation of solid phases; Table 2$)$. Although outcrops of gabbroic cumulates that could corroborate the fractionation models are lacking in Búzios, it should be noted that these types of rocks crop out on the neighboring islands of Monte de Trigo (Enrich et al. 2005, 2009) and São Sebastião (Bellieni et al. 1990) and are also very common in several other alkaline districts from Southeastern Brazil, such as Jacupiranga, Juquiá and Pariquera-Açu (Morbidelli et al. 2000; Gomes et al. 2011) and Ponte Nova (Azzone et al. 2013, 2016).

It is also important to note the clear compositional gap shown in the variation diagrams of the Búzios rocks, especially for major elements (Fig. 9), pointing to the absence of compositions between 50 and $60 \mathrm{wt} \% \mathrm{SiO}_{2}$ (an interval referred in the literature as the "Daly gap", cf. Chayes, 1977). This gap can be interpreted as a consequence of the viscosity increase during the magmatic evolution that would prevent the migration of magma

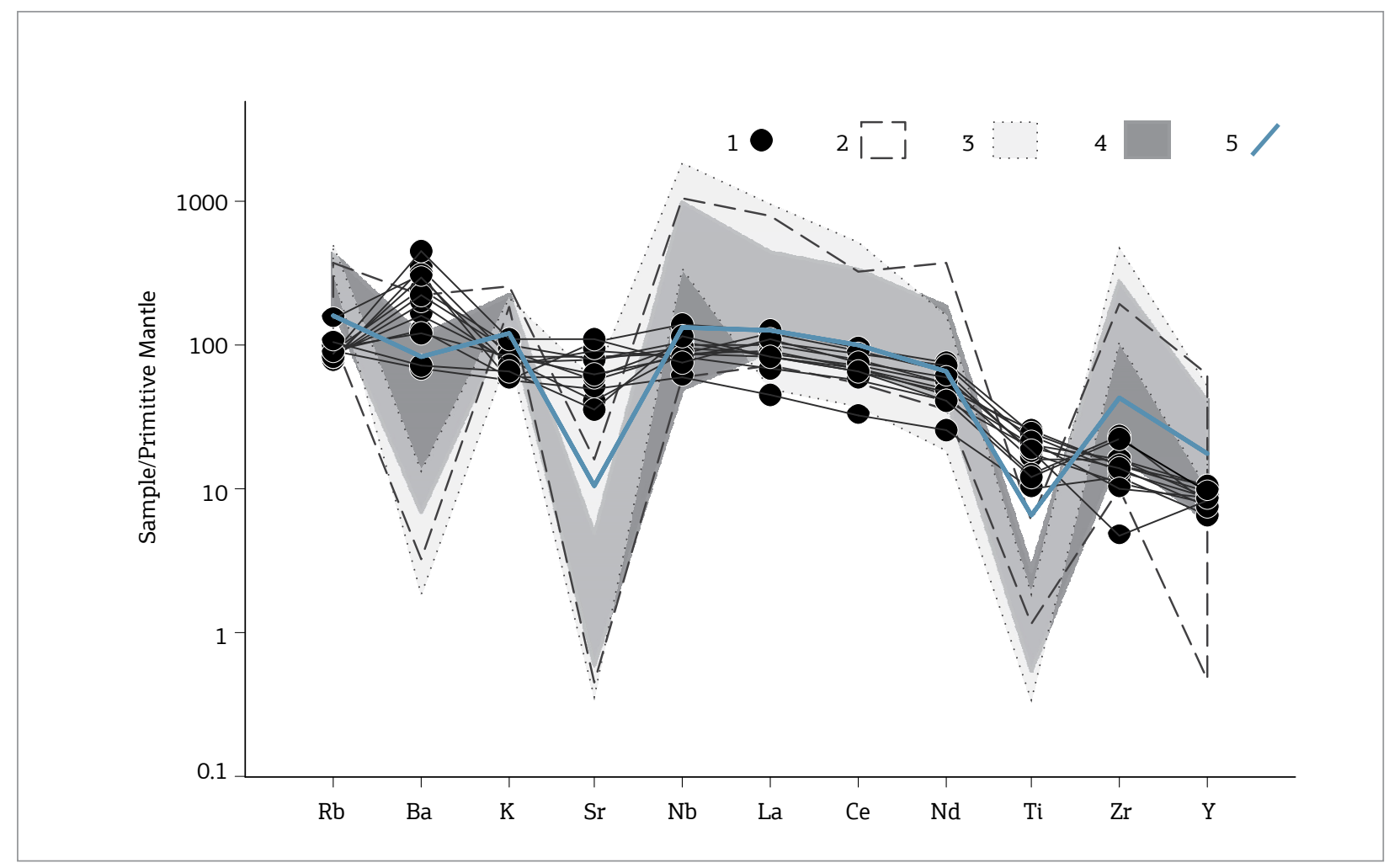

Figure 11. Primitive mantle-normalized trace elements patterns (cf. McDonough \& Sun 1995) for the Búzios rocks (after Alves 1997). Legends: 1. Mafic-ultramafic dikes; 2. syenites; 3. phonolites; 4. rhyolites; 5. mangerite host rock. 
with intermediate compositions to low crustal levels (e.g., Thompson et al. 2001). Alternatively, it could be the result of two distinct parental magmas, a mafic and a felsic one (e.g., Legendre et al. 2005). This latter hypothesis usually leads to the mixture of mafic and felsic melts. However, there is no description of field, petrographic or chemical evidences of magma mixing in the area (Alves 1997; Alves \& Gomes 2001).

In the petrogeny residual system (Fig. 12, after Hamilton \& Mackenzie 1965), the Búzios felsic rocks are compatible with major fractionation of alkali feldspar and plot differently with respect to the low-pressure Ab-Or thermal barrier. A trend towards the phonolitic minimum characterizes the $\mathrm{SiO}_{2}$-undersaturated association (felsic dikes of nepheline/ sodalite-bearing rocks), whereas a trend towards the rhyolitic minimum is associated with the $\mathrm{SiO}_{2}$-oversaturated rocks (felsic dikes of rhyolites). According to Alves (1997), the first trend seems to be related to the normal evolution of the syenitic magma. Mineral vectors on the $\mathrm{Na}_{2} \mathrm{O}$ vs. $\mathrm{K}_{2} \mathrm{O}$ diagram (Fig. 8) also indicate the alkali feldspar fractionation from a syenitic magma towards a phonolite liquid and suggest that some syenites are alkali feldspar cumulates. The second trend

Table 2. Summary of thermodynamic fractional crystallization models developed using the MELTS algorithm (Ghiorso and Sack, 1995) from a basanitic liquid compositionally similar to sample 326a. The starting composition is found under isobaric conditions ( $1 \mathrm{kbar}$ ) and with $\mathrm{fO}_{2}$ conditions equal to the QFM buffer. Abbreviations: Ap, apatite; Cpx, clinopyroxene; Ol, olivine; Pl, plagioclase; Spl, spinel group.

\begin{tabular}{|l|c|c|c|c|c|c|c|c|c|c|c|c|c|c|c|}
\hline Steps & 1 & 2 & 3 & 4 & 5 & 6 & 7 & 8 & 9 & 10 & 11 & 12 & 13 & 14 & 15 \\
\hline T ( ${ }^{\circ}$ C) & 1176 & 1156 & 1136 & 1116 & 1096 & 1076 & 1056 & 1036 & 1016 & 996 & 976 & 956 & 936 & 916 & 896 \\
\hline $\begin{array}{l}\text { Fractionated } \\
\text { solids (f\%) }\end{array}$ & 0.0 & 1.5 & 3.2 & 7.5 & 24.1 & 34.1 & 41.7 & 48.6 & 53.7 & 57.7 & 61.0 & 63.8 & 66.3 & 68.4 & 70.4 \\
\hline
\end{tabular}

MELT compositions

\begin{tabular}{|c|c|c|c|c|c|c|c|c|c|c|c|c|c|c|c|}
\hline $\mathrm{SiO}_{2}$ & 43.52 & 43.59 & 43.73 & 44.98 & 47.91 & 50.60 & 52.63 & 54.39 & 55.82 & 56.99 & 57.98 & 58.81 & 59.49 & 60.04 & 60.48 \\
\hline $\mathrm{TiO}_{2}$ & 4.31 & 4.37 & 4.41 & 3.95 & 2.75 & 2.04 & 1.64 & 1.40 & 1.22 & 1.08 & 0.96 & 0.86 & 0.78 & 0.72 & 0.66 \\
\hline $\mathrm{Al}_{2} \mathrm{O}_{3}$ & 14.08 & 14.29 & 14.53 & 14.93 & 16.27 & 17.57 & 18.04 & 17.91 & 17.68 & 17.38 & 17.03 & 16.67 & 16.31 & 15.95 & 15.59 \\
\hline $\mathrm{Fe}_{2} \mathrm{O}_{3}$ & 2.21 & 2.23 & 2.24 & 2.10 & 1.74 & 1.45 & 1.24 & 1.07 & 0.93 & 0.81 & 0.71 & 0.63 & 0.55 & 0.47 & 0.41 \\
\hline $\mathrm{FeO}$ & 10.18 & 10.08 & 9.90 & 8.77 & 6.93 & 5.69 & 4.73 & 3.92 & 3.27 & 2.74 & 2.31 & 1.94 & 1.62 & 1.35 & 1.12 \\
\hline $\mathrm{MnO}$ & 0.17 & 0.17 & 0.16 & 0.17 & 0.20 & 0.23 & 0.26 & 0.28 & 0.31 & 0.32 & 0.34 & 0.35 & 0.37 & 0.38 & 0.39 \\
\hline $\mathrm{MgO}$ & 7.17 & 6.65 & 6.09 & 5.45 & 4.15 & 3.23 & 2.61 & 2.14 & 1.80 & 1.52 & 1.30 & 1.12 & 0.97 & 0.84 & 0.74 \\
\hline $\mathrm{CaO}$ & 10.54 & 10.69 & 10.87 & 11.21 & 9.88 & 8.21 & 7.02 & 6.11 & 5.38 & 4.78 & 4.28 & 3.86 & 3.50 & 3.21 & 2.96 \\
\hline $\mathrm{Na}_{2} \mathrm{O}$ & 3.08 & 3.13 & 3.18 & 3.33 & 4.01 & 4.59 & 5.03 & 5.39 & 5.68 & 5.89 & 6.05 & 6.17 & 6.25 & 6.30 & 6.31 \\
\hline $\mathrm{K}_{2} \mathrm{O}$ & 2.06 & 2.09 & 2.12 & 2.22 & 2.70 & 3.11 & 3.51 & 3.96 & 4.37 & 4.76 & 5.14 & 5.50 & 5.86 & 6.21 & 6.55 \\
\hline $\mathrm{P}_{2} \mathrm{O}_{5}$ & 1.49 & 1.51 & 1.54 & 1.61 & 1.88 & 1.53 & 1.32 & 1.19 & 1.10 & 1.03 & 0.99 & 0.96 & 0.94 & 0.95 & 0.96 \\
\hline $\mathrm{H}_{2} \mathrm{O}$ & 0.99 & 1.00 & 1.02 & 1.07 & 1.30 & 1.47 & 1.64 & 1.84 & 2.04 & 2.23 & 2.41 & 2.59 & 2.78 & 2.96 & 3.16 \\
\hline $\mathrm{CO}_{2}$ & 0.20 & 0.20 & 0.20 & 0.21 & 0.26 & 0.30 & 0.34 & 0.38 & 0.43 & 0.47 & 0.51 & 0.55 & 0.58 & 0.62 & 0.67 \\
\hline Total & 100.00 & 100.00 & 99.99 & 100.00 & 99.98 & 100.02 & 100.01 & 99.98 & 100.03 & 100.00 & 100.01 & 100.01 & 100.00 & 100.00 & 100.00 \\
\hline
\end{tabular}

$\%$ of solid phases (in equilibrium with each step)

\begin{tabular}{|c|c|c|c|c|c|c|c|c|c|c|c|c|c|c|}
\hline Cpx & & & 0.66 & 12.39 & 6.86 & 3.1 & 1.13 & 0.6 & 0.32 & 0.17 & 0.11 & 0.08 & 0.06 & 0.05 \\
\hline Ol & 1.46 & 1.52 & 1.23 & 0.09 & 0.06 & 0.31 & 0.54 & 0.4 & 0.33 & 0.29 & 0.23 & 0.18 & 0.14 & 0.11 \\
\hline Spl & & 0.16 & 2.45 & 4.06 & 2.07 & 1.39 & 1.05 & 0.71 & 0.5 & 0.35 & 0.27 & 0.21 & 0.16 & 0.13 \\
\hline $\mathrm{Pl}$ & & & & & & 2.3 & 3.81 & 3.18 & 2.74 & 2.41 & 2.14 & 1.93 & 1.77 & 1.94 \\
\hline Ap & & & & 0.14 & 1 & 0.57 & 0.38 & 0.25 & 0.17 & 0.13 & 0.1 & 0.07 & 0.05 & 0.04 \\
\hline
\end{tabular}

$\%$ of accumulated fractionated phases from previous steps

\begin{tabular}{|c|c|c|c|c|c|c|c|c|c|c|c|c|c|}
\hline Cpx & & & 0.65 & 13.04 & 19.89 & 22.98 & 24.11 & 24.71 & 25.03 & 25.19 & 25.3 & 25.38 & 25.43 \\
\hline $\mathrm{Ol}$ & 1.46 & 2.98 & 4.21 & 4.29 & 4.36 & 4.67 & 5.2 & 5.6 & 5.93 & 6.22 & 6.45 & 6.63 & 6.77 \\
\hline Spl & & 0.16 & 2.61 & 6.66 & 8.73 & 10.11 & 11.16 & 11.87 & 12.36 & 12.7 & 12.97 & 13.17 & 13.33 \\
\hline $\mathrm{Pl}$ & & & & & & 2.29 & 6.1 & 9.29 & 12.03 & 14.43 & 16.57 & 18.5 & 20.26 \\
\hline Ap & & & & 0.14 & 1.13 & 1.69 & 2.07 & 2.31 & 2.48 & 2.61 & 2.7 & 2.76 & 2.81 \\
\hline
\end{tabular}


could be the result of moderate water pressures adequate to promote the oversaturation of the magma in lower temperature zones (e.g., at the margins of the intrusion), leading to the destabilization of the clinopyroxene and formation of amphibole and/or biotite, with $\mathrm{SiO}_{2}$ in excess. Studying the Itatiaia massif, which also contains $\mathrm{SiO}_{2}$-undersaturated and $\mathrm{SiO}_{2}$-oversaturated rocks, Brotzu et al. (1997) suggested that a fractionation process dominated by silica-poor and alkali-rich amphibole is a possible way to straddle the Ab-Or join in the Qz-Ne-Ks diagram. The authors postulated that variations in mineral composition, mainly of amphibole, of the least differentiated syenites excluded the possibility of a direct link between the two suites, and proposed for such lithologies a genesis from distinct mafic parental magmas showing different degrees of $\mathrm{SiO}_{2}$ saturation. This conclusion could also be applied to the Búzios rocks.

The bridging of the thermal barrier may also be explained by AFC processes (DePaolo 1981). In some alkaline intrusions from Southeastern Brazil, such as Itatiaia (Brotzu et al. 1997) and Cananeia (Spinelli \& Gomes 2009), silica-oversaturated syenitic rocks occurring as small dikes appear to have been influenced by crustal contamination or AFC processes, as mainly indicated by the high ${ }^{87} \mathrm{Sr} /{ }^{86} \mathrm{Sr}$ initial ratios (>0.705, cf. Ruberti et al. 2005). Unfortunately, no isotopic data are available for the Búzios rhyolitic rocks. Crustal assimilation processes are believed to play an important role in the genesis of other alkaline intrusions of Southern Brazil, as suggested by Motoki (1986) and Motoki et al. (2015) for the neighboring Vitória Island and the Cabo Frio massif, as well as by Azzone et al. (2016) for the mafic-ultramafic complex of Ponte Nova.

The last alkaline magmatic activity in Búzios is represented by the numerous dikes that vary compositionally from lamprophyres to $\mathrm{SiO}_{2}$-undersaturated (phonolites) to $\mathrm{SiO}_{2}$-oversaturated (rhyolites) rocks. Such dikes could either

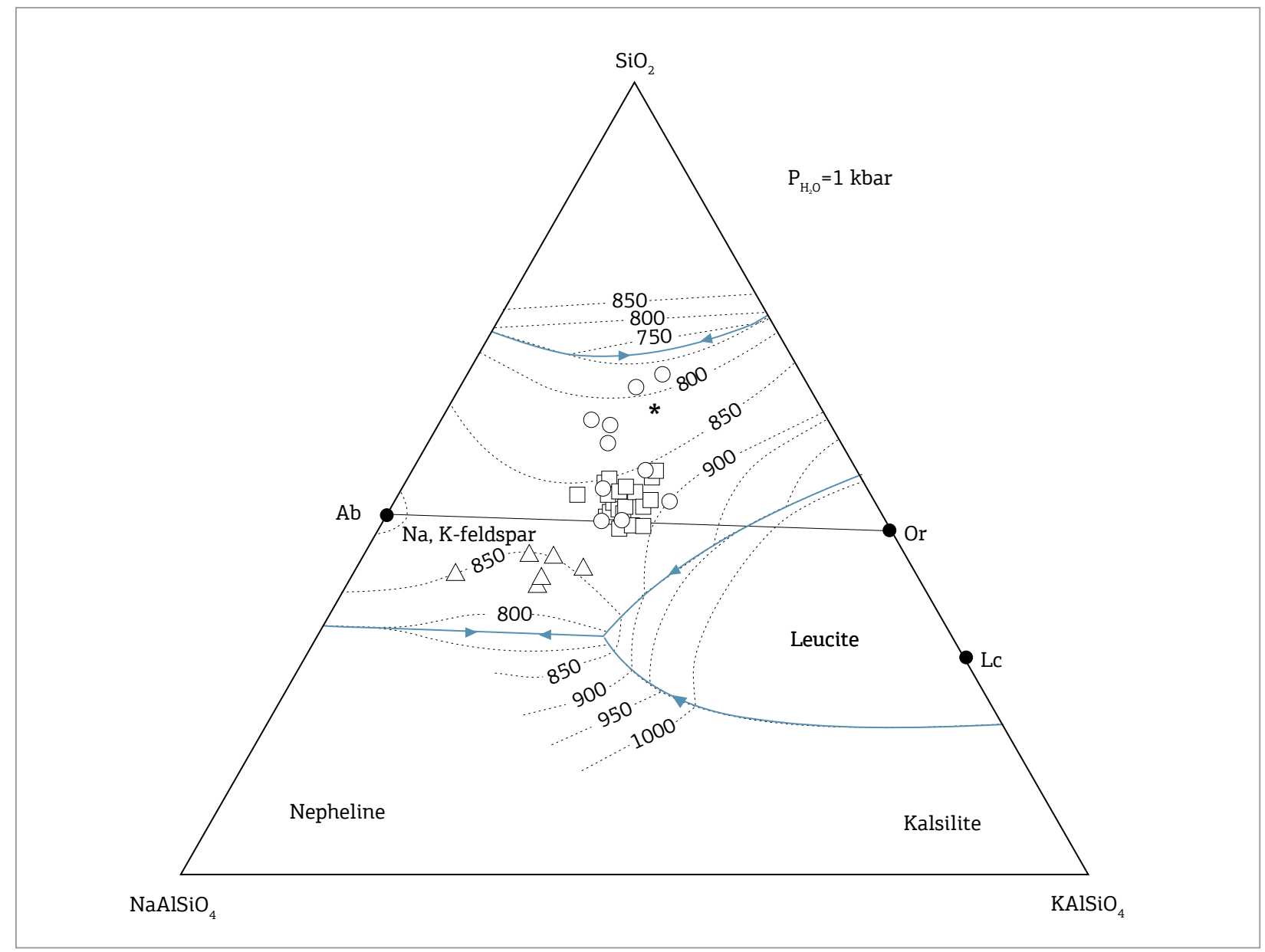

Figure 12. The Búzios rocks plotted in the normative Qz-Ne-Ks residual system at $P_{\mathrm{H} 2 \mathrm{O}}=1$ kbar (after Hamilton and MacKenzie 1965). Isotherms and cotectic lines after Hall (1987). Symbols: open square, syenite; open circle, trachyte and rhyolite dikes; open triangle, nepheline (sodalite) microsyenite and phonolite dikes; asterisk, average composition of charnockitic rocks from the Ubatuba area (cf. Neumann 1993). 
be part of a single magmatic sequence formed by fractional crystallization or represent different pulses of undersaturated alkaline magmas.

\section{FINAL REMARKS}

Geological evidence indicates that Precambrian formations of the Ribeira Belt were probably intruded by different pulses of alkaline magma on Búzios Island. The emplacement of these magmas, and also of other alkaline rocks on the neighboring islands, is clearly controlled by regional tectonics, as already suggested by Almeida (1983) and Riccomini et al. (2005).

Similar to other alkaline centers from Southeastern Brazil (Morbidelli et al., 1995), which show the presence of volcanic structures and lithotypes (e.g., Itatiaia, Piratini, Poços de Caldas, Tunas) or of cumulate rocks occupying shallow stratigraphic positions (e.g., Jacupiranga), the syenitic magmatic activity in Búzios was developed under low-pressure conditions.

The Búzios alkaline rocks can be placed into two main assemblages. The first and most abundant group includes plutonic felsic types, mostly alkali feldspar syenites and minor amounts of quartz-alkali feldspar syenites. Also belonging to this association are dikes, widely variable in composition, with microsyenites and trachytes as the main petrographic types. The second assemblage consists of mafic to ultramafic rocks that occur as small lamprophyric dikes (alkali basalts, basanites, tephrites, and trachybasalts). In contrast to Monte de Trigo and São Sebastiáo Islands, and like Vitória Island, Búzios does not have outcrops of plutonic alkaline basic rocks.

Mineralogically, the Búzios lithologies have alkali feldspar (mesoperthite), clinopyroxenes (diopsidic to aegirinic in composition), amphiboles (Mg-hornblende evolving towards more calcic-sodic types), micas (Mg-biotites to Fe-biotites), opaques (magnetite and ilmenite), and quartz as principal phases, with feldspathoids (nepheline and subordinate sodalite) occasionally present in fine-grained syenites, and plagioclase in more basic rocks. In the lamprophyric varieties, the amphibole is kaersutite, olivine occurs, and the biotite is Ti-rich. In addition to ore phases, the accessory mineralogy of the syenitic rocks includes apatite, titanite, zircon, fluorite, and rare Ti-Zr-REE silicate phases, while zeolites and carbonates are the more common alteration products. Also notable is the presence of globules and ocelli of variable mineralogical composition (analcite, glass and/or carbonates) in the lamprophyric rocks.

Excluding the lamprophyric rocks, textural evidence indicates that, after the formation of opaques, clinopyroxenes are the first mafic minerals to be crystallized in the magma. They occur as isolated crystals or are clearly surrounded by amphibole/biotite grains in the more advanced stages of magmatic crystallization. Alkali feldspar appears to have been formed simultaneously with both mafic minerals.

Zoning is particularly common in the clinopyroxenes, with the central areas of the crystals exhibiting lighter greenish colours. Changes in color reflect the variations in the chemical composition as follows: the increase in $\mathrm{Fe}$ and $\mathrm{Na}$ contents and the concomitant decrease in $\mathrm{Mg}$ from the cores to the rims of the crystals.

The chemical analyses of the Búzios rocks show a compositional gap in $\mathrm{SiO}_{2}$ content (between 50 and $60 \mathrm{wt} \%$ ), which corresponds to the interval between syenites and mafic-ultramafic dikes. This bimodal distribution is also suggested for other major elements, particularly $\mathrm{FeO}, \mathrm{MgO}$, $\mathrm{CaO}$, and $\mathrm{K}_{2} \mathrm{O}$. Overall, the rocks are typically potassic, although some dikes can be chemically classified as sodic, peralkaline and agpaitic in composition.

The fractional crystallization of gabbroic cumulates from a basanite melt is considered to be responsible for the formation of the syenite magma of the island. MELTS models indicate the fractionation of $-7 \mathrm{wt} \%$ olivine, $-24 \mathrm{wt} \%$ clinopyroxene, $-22 \mathrm{wt} \%$ plagioclase, $-13 \mathrm{wt} \%$ spinel, and $-3 \mathrm{wt} \%$ apatite ( $-65 \%$ fractionation of solid phases) to reach the syenite compositions.

Similar to other Brazilian alkaline districts (e.g., Itatiaia), Búzios has $\mathrm{SiO}_{2}$-undersaturated and $\mathrm{SiO}_{2}$-oversaturated rocks represented by felsic dikes of phonolitic and rhyolitic composition, respectively. In the normative Qz-Ne-Ks petrogeny residual diagram, these compositions exhibit distinct behavior, trending towards the eutectic phonolitic minimum and the rhyolitic minimum, respectively. The first trend is possibly associated with the normal evolution of the syenitic magma, with extensive fractionation of alkali feldspar. On the other hand, the trend towards the granitic eutectic may be due to alkali feldspar fractionation or to fractionation of amphibole, or it may be the result of AFC processes, a hypothesis that cannot be discarded because the almost total absence of isotopic data for the Búzios rocks.

\section{ACKNOWLEDGEMENTS}

The authors would like to thank Fundação de Amparo à Pesquisa do Estado de São Paulo (Fapesp) (Process no. 13/18073-4, CBG.; 2010/20425-8, RGA; 2006/01459-3 and 2010/20476-1, GEER; 2012/06082-6, ER) for financial support. We thank Professors L. F. Scheibe and A. Marzoli for their constructive comments that improved the manuscript. 


\section{REFERENCES}

Almeida F.F.M. 1983. Relações tectônicas das rochas alcalinas mesozoicas da região meridional da Plataforma Sul-Americana. Revista Brasileira de Geociências, 13:139-158.

Alves F.R. 1997. Contribuição ao conhecimento geológico e petrográfico das rochas alcalinas da Ilha dos Búzios, SP. PhD Thesis, Instituto de Geociências, Universidade de São Paulo, 274 p.

Alves F.R. \& Gomes C.B. 2001. Ilha dos Búzios, Litoral Norte do Estado de São Paulo: aspectos geológicos e petrográficos. Geologia USP, Série Científica, 1:101-114.

Alves F.R. \& Gomes C.B. 2002. Idades das rochas alcalinas do Litoral do Estado de São Paulo: a Ilha dos Búzios. In: XLI Congresso Brasileiro de Geologia, João Pessoa, Anais, p. 535.

Amaral G., Bushee J., Cordani U.G., Kawashita K., Reynolds J.H. 1967. Potassium-argon ages of alkaline rocks from southern Brazil. Geochimica et Cosmochimica Acta, 31:117-142.

Asimow P.D. \& Ghiorso M.S. 1998. Algorithmic Modifications Extending MELTS to Calculate Subsolidus Phase Relations. American Mineralogist, 83:1127-1131.

Augusto T. \& Vlach S.R.F. 2004. Ocorrência e quimismo de minerais dos grupos da chevkinita e do pirocloro em rocha sienítica da Ilha de São Sebastião. In: XLII Congresso Brasileiro de Geologia, Araxá, $C D-R O M$.

Azzone R.G., Enrich G.E.R., Gomes C.B., Ruberti E. 2013. Trace element composition of parental magmas from mafic-ultramafic cumulates determined by in situ mineral analyses: the Juquiá mafic-ultramafic alkaline-carbonatite massif, SE Brazil. Journal of South American Earth Sciences, 41:5-21.

Azzone R.G., Montecinos Munoz P., Enrich G.E.R., Alves A., Ruberti E., Gomes C.B. 2016. Petrographic, geochemical and isotopic evidence of crustal assimilation processes in the Ponte Nova alkaline maficultramafic massif, SE Brazil. Lithos, 260:58-75.

Azzone R.G., Ruberti E., Enrich G.E.R., Gomes C.B. 2009. Geologia e geocronologia do maciço alcalino máfico-ultramáfico Ponte Nova (SP-MG). Geologia USP, Série Científica, 9:23-46.

Barbieri M., Beccaluva L., Brotzu P., Conte A., Garbarino C., Gomes C.B., Loss E.L., Macciotta G., Morbidelli L., Scheibe L.F., Tamura R.M., Traversa G. 1987. Petrological and geochemical studies of alkaline rocks from continental Brazil. 1. The phonolite suite from Piratini, RS. Geochimica Brasiliensis, 1:109-138.

Beccaluva L., Born H., Brotzu P., Coltorti M., Conte A.M., Garbarino C., Gomes C.B., Loss E.L., Macciotta G., Morbidelli L., Ruberti E., Siena F, Traversa G. 1992. Fractional crystallization and liquid immiscibility processes in the alkaline-carbonatite complex of Juquiá (São Paulo State, Brazil). Journal of Petrology, 33:1371-1404.

Bellezza M., Merlino S., Perchiazzi N. 2009. Mosandrite: structural and crystal-chemical relationships with rinkite. The Canadian Mineralogist, 47:897-908.

Bellieni G., Montes-Lauar C.R., De Min A., Piccirillo E.M., Cavazzini G., Melfi A.J., Pacca I.G. 1990. Early and Late Cretaceous magmatism from São Sebastião Island (SE-Brazil): geochemistry and petrology. Geochimica Brasiliensis, 4:59-83.

Björnberg A.J.S. \& Ellert R. 1955. Observações geológicas e petrográficas sobre a Ilha dos Búzios. Anais da Academia Brasileira de Ciências, 27:169-182.

Brotzu P., Barbieri M.. Beccaluva L., Garbarino C.. Gomes C.B., Macciotta G., Melluso L., Morbidelli L., Ruberti E., Sígolo J.B. 1992. Petrology and geochemistry of the Passa Quatro alkaline complex, MG-RJ-SP, Brazil. Journal of South American Earth Sciences, 6:237-252.
Brotzu P., Beccaluva L., Conte A.M., Fonseca M., Garbarino C., Gomes C.B., Leong R., Macciotta G., Mansur R.L., Melluso L., Morbidelli L., Ruberti E., Sígolo J.B., Traversa G., Valença J.G. 1989. Petrological and geochemical studies of alkaline rocks from continental Brazil. 8. The syenitic intrusion of Morro Redondo, RJ. Geochimica Brasiliensis, 3:63-80

Brotzu P., Gomes C.B., Melluso L., Morbidelli L., Morra V., Ruberti E. 1997. Petrogenesis of coexisting $\mathrm{SiO}_{2}$-undersaturated to $\mathrm{SiO}_{2}-$ oversaturated felsic igneous rocks: the alkaline complex of Itatiaia, southeastern Brazil. Lithos, 40:133-156.

Brotzu P., Melluso L., Bennio L., Gomes C.B., Lustrino M., Morbidelli L., Morra V., Ruberti E., Tassinari C.C.G, D’Antonio M. 2007. Petrogenesis of the Early Cenozoic potassic alkaline complex of Morro de São João, southeastern Brazil. Journal of South American Earth Sciences, 24:93-115.

Buddington A.F. \& Lindsley D.H. 1964. Iron-titanium oxide minerals and synthetic equivalents. Journal of Petrology, 5:310-357.

Christiansen C.C., Johnsen O., Makovicky E. 2003. Crystal chemistry of the rosenbuschite group. The Canadian Mineralogist, 41:1203-1224.

Chayes F. 1977. The oceanic basalt-trachyte relation in general and in the Canary Islands. American Mineralogist, 62:666-671.

Coutinho J.M.V. \& Melcher G.C. 1973. Levantamento geológico e petrográfico na Ilha do Monte de Trigo (Litoral Norte de São Paulo, Brasil). Revista Brasileira de Geociências, 3:243-256

DePaolo D.J. 1981. Trace element and isotopic effects of combined wallrock assimilation and fractional crystallization. Earth Planetary Science Letters, 53:189-201.

Enrich G.E.R. 2005. Petrogênese da suite alcalina da Ilha Monte de Trigo, SP. PhD Thesis, Instituto de Geociências, Universidade de São Paulo, $229 \mathrm{p}$

Enrich G.E.R., Azzone R.G., Ruberti E., Gomes C.B. 2005. Itatiaia, Passa Quatro and São Sebastião Island, the major alkaline syenitic complexes from the Serra do Mar region. In: Comin-Chiaramonti P., Gomes C.B. (eds.). Mesozoic to Cenozoic alkaline magmatism in the Brazilian Platform. Edusp/Fapesp, São Paulo, p. 419-442.

Enrich G.E.R., Ruberti E., Azzone R.G., Gomes C.B. 2016. Eudyalitegroup minerals from the Monte de Trigo Island alkaline suite (Brazil): chemical composition and petrological implications. Brazilian Journal of Geology 46:411-426.

Enrich G.E.R., Ruberti E., Gomes C.B. 2009. Geology and geochronology of Monte de Trigo island alkaline suíte, southeastern Brazil. Revista Brasileira de Geociências, 39:67-80.

Freitas R.O. 1947. Geologia e petrologia da Ilha de São Sebastião. Boletim da Faculdade de Filosofia, Ciências e Letras da Universidade de São Paulo, 85:1-244.

Garda G.M. 1995. Os diques básicos e ultrabásicos da região costeira entre as cidades de São Sebastião e Ubatuba, Estado de São Paulo. PhD Thesis, Instituto de Geociências, Universidade de São Paulo,156 p.

Ghiorso M.S. \& Sack R.O. 1995. Chemical mass transfer in magmatic processes. IV. A revised and internally consistent thermodynamic model for the interpolation and extrapolation of liquid-solid equilibria in magmatic systems at elevated temperatures and pressures. Contributions to Mineralogy and Petrology, 119:197-212.

Gomes C.B., Ruberti E., Comin-Chiaramonti P., Azzone R.G. 2011. Alkaline magmatism in the Ponta Grossa Arch, SE Brazil: a review. Journal of South American Earth Sciences, 32:152-168. 
Hall A. 1987. Igneous petrology. Longman Scientific Technical, 573 p.

Hamilton D.L. 1961. Nepheline as crystallization temperature indicators. Journal of Geology, 69:321-329.

Hamilton D.L. \& MacKenzie W.S. 1965. Phase equilibrium studies in the system $\mathrm{NaAlSiO}_{4}$ (nepheline)- $\mathrm{KAlSiO}_{4}$ (kalsilite) $-\mathrm{SiO}_{2}-\mathrm{H}_{2} \mathrm{O}$. Mineralogical Magazine, 34:214-231.

Heilbron M., Valeriano C.M., Tassinari C.C.G., Almeida J., Tupinambá, M., Siga Jr., O., Trouw R.A.J. 2008. Correlation of Neoproterozoic terranes between the Ribeira Belt, SE Brazil, and its African counterpart: comparative tectonic evolution and open questions. In: Pankhurst R.J., Trouw, R.A.J., Brito Neves B.B., De Wit M.J. (eds.). West Gondwana: Pre-Cenozoic correlations across the South Atlantic region. Geological Society of London, Special Publications, 294:211-237.

Hennies W.T. \& Hasui Y. 1968. Geocronologia das rochas eruptivas da Ilha de São Sebastião, SP. In: XXII Congresso Brasileiro de Geologia, Belo Horizonte, Anais, p.145-148.

Hennies W.T. \& Hasui Y. 1977. Contribuição ao reconhecimento da geologia da Ilha de São Sebastião. In: I Simpósio de Geologia Regional, São Paulo, Atas, p.199-209.

Johnsen O., Ferraris G., Gault R.A., Grice J.D., Kampf A.R., Pekov I.V. 2003. The nomenclature of eudyalite-group minerals. The Canadian Mineralogist, 41:785-794.

Le Maitre R.W. 1989. A classification of igneous rocks and glossary of terms. Blackwell Science Publication, Oxford.

Leake B.E. 1997. Nomenclature of amphiboles. Report of the Subcommittee on Amphiboles of the International Mineralogical Association Commission on New Minerals and Mineral Names. European Journal of Mineralogy, 9:623-651.

Legendre C., Maury R.C., Caroff M., Guillou H., Cotton J., Chauvel C., Bollinger C., Hémond C., Guille G., Blais S., Rossi P., Savanier D. 2005. Origin of exceptionally abundant phonolites on Ua Pou Island (Marquesas, French Polynesia): partial melting of basanites followed by crustal contamination. Journal of Petrology, 46:1925-1962.

Lima G.A. \& Schorscher J.H.D. 1999. Complexo gábrico estratiforme da Ponta da Pacuíba, Ilha de São Sebastião, São Paulo. In: 6. ${ }^{\circ}$ Simpósio de Geologia do Sudeste, São Pedro, Boletim de Resumos, p. 65.

Marks M.A.W., Schilling J., Coulson I.M., Wenzel T., Markl G. 2008. The alkaline-peralkaline Tamazeght complex, High Atlas Mountains, Morocco: mineral chemistry and petrological constraints for derivation from a compositionally heterogeneous mantle source. Journal of Petrology, 49:1097-1131.

McDonough W.F. \& Sun S. 1995. The composition of the Earth. Chemical Geology, 120:223-253.

Menezes S.G., Azzone R.G., Enrich G.E.R., Ruberti E., Cagliarani R., Gomes C.B., Chmyz L. 2015. The antecryst compositional influence on Cretaceous alkaline lamprophyre dykes, SE Brazil. Brazilian Journal of Geology, 45:79-93.

Merlino S. \& Perchiazzi N. 1988. Modular mineralogy in the cuspidine group of minerals. The Canadian Mineralogist, 26:933-943.

Middlemost E.A.K. 1975. The basalt clan. Earth Science Reviews, 11:337-364.

Montes-Lauar C.R., Pacca I.G., Melfi A.J., Kawashita K. 1995. Late Cretaceous alkaline complexes, southeastern Brazil: paleomagnetism and geochronology. Earth and Planetary Science Letters, 134:425-440.

Morbidelli L. Gomes C.B., Beccaluva L., Brotzu P., Conte A.M., Ruberti E., Traversa G. 1995. Mineralogical, petrological and geochemical aspects of alkaline and alkaline-carbonatite associations from Brazil. Earth-Science Reviews, 39:135-168.
Morbidelli L., Gomes C.B., Brotzu P., D’Acquarica S., Garbarino C., Ruberti E., Traversa G. 2000. The Pariquera-Açu K-alkaline complex and southern Brazil lithospheric mantle source characteristics. Journal of Asian Earth Sciences, 18:129-150.

Morimoto N., Fabries J., Ferguson A.K., Ginzburg I.V., Ross M., Seifert F.A., Zussmann J., Aoki A., Gotardi G. 1988. Nomenclature of pyroxenes. American Mineralogist, 73:1123-1133.

Motoki A. 1986. Geologia e petrologia do maciço alcalino da Ilha de Vitória, SP. PhD Thesis, Instituto de Geociências, Universidade de São Paulo, 245 p.

Motoki A. 2000. Nepheline syenite magma superheating of the Vitória Island syenitic intrusive rock body, São Paulo, Brazil. In: $31^{\text {st }}$ International Geology Congress, Rio de Janeiro, Abstracts, CD-ROM

Motoki A. \& Gomes C.B. 1984. Caracterização geológica e petrográfica do maciço alcalino da Ilha de Vitória, SP. In: XXXIII Congresso Brasileiro de Geologia, Rio de Janeiro, Anais, 9:4392-4399.

Motoki A., Gomes C.B., Dutra C.V. 1987. Assimilação de rochas encaixantes pelo magma nefelina sienítico do maciço alcalino da Ilha de Vitória, SP. In: 1. ${ }^{\circ}$ Congresso Brasileiro de Geoquímica, Porto Alegre, v. 1, p. 375-397.

Motoki A., Sichel S.E., Vargas T., Melo D.P., Motoki K.F. 2015. Geochemical behaviour of trace elements during fractional crystallization and crustal assimilation of the felsic alkaline magmas of the state of Rio de Janeiro, Brazil. Anais da Academia Brasileira de Ciências, 87:1959-1979.

Neumann R. 1993. Contribuição à petrologia das rochas charnockíticas de Ubatuba, leste do Estado de São Paulo. MSc Dissertation, Instituto de Geociências, Universidade de São Paulo, 86 p.

Nimis, P. 1995. A clinopyroxene geobarometer for basaltic systems based on crystal-structure modeling. Contributions to Mineralogy and Petrology, 121: 115-125.

Nimis P. 1995. A clinopyroxene geobarometer for basaltic systems based on crystal-structure modeling. Contributions to Mineralogy and Petrology, 121:115-125.

Piilonen C., Mcdonald M., Lalonde E. 2003. Insights into astrophyllitegroup minerals. II. Crystal chemistry. The Canadian Mineralogist, 41:27-54.

Putirka K.D. 2008. Thermometers and barometers for volcanic systems. Reviews in Mineralogy \& Geochemistry, 69:61-120.

Riccomini C., Velázquez V.F., Gomes C.B. 2005. Tectonic controls of the Mesozoic to Cenozoic alkaline magmatism in centralsoutheastern Brazilian Platform. In: Comin-Chiaramonti P., Gomes C.B. (eds.). Mesozoic to Cenozoic alkaline magmatism in the Brazilian Platform. Edusp/Fapesp, São Paulo, p. 31-55.

Ruberti E., Gomes C.B., Comin-Chiaramonti P. 2005. The alkaline magmatism from the Ponta Grossa Arch. In: Comin-Chiaramonti P., Gomes C.B. (eds.). Mesozoic to Cenozoic alkaline magmatism in the Brazilian Platform. Edusp/Fapesp, São Paulo, p. 473-522.

Sato E.N., Vlach, S.R.F., Basei M.A.S. 2008. Zircon and baddeleyite U-Pb dating (TIMS) of Mesozoic alkaline rocks from the São Sebastião Island, southeastern Brazil. In: $33^{\text {rd }}$ International Geological Congress, Oslo, Abstracts, CD-ROM.

Schilling J., Wu F.-Y., McCammon C., Wenzel T., Marks M.A.W., Pfaff K., Jacob D.E., Markl G. 2011a. The compositional variability of eudialyte-group minerals. Mineralogical Magazine, 75:87-115.

Siga Jr. O., Gomes C.B., Sato K., Passarelli C.R. 2007. O maciço alcalino de Tunas, PR: novos dados geocronológicos. Geologia USP, Série Científica, 7:71-80 
Sonoki I.K. \& Garda G.M. 1988. Idades K-Ar de rochas alcalinas do Brasil Meridional e Paraguai Oriental: compilação e adaptação às novas constantes de decaimento. Boletim IG-USP, Série Científica, 19:63-85.

Sörensen H. 1960. On the agpaitic rocks. In: XXI International Geological Congress, Norway, Part XIII, p. 319-327.

Spinelli F.P. \& Gomes C.B. 2009. A ocorrência alcalina de Cananeia, litoral sul do Estado de São Paulo: petrologia e geoquímica. Revista Brasileira de Geociências, 39:304-323.

Thompson G.M., Smith I.E.M., Maipas J.G. 2001. Origin of oceanic phonolites by crystal fractionation and the problem of the Daly gap: an example from Rarotonga. Contributions to Mineralogy and Petrology, 142:336-346.
Traversa G., Barbieri M., Beccaluva L., Coltorti M., Conte A.M. Garbarino C., Gomes C.B., Macciotta G., Morbidelli L., Ronca S., Scheibe L.F. 1996. Mantle sources and differentiation of alkaline magmatic suite of Lages, Santa Catarina, Brazil. European Journal of Mineralogy, 8:193-208.

Trumbull R.B., Buhn B., Romer R.L., Volker F. 2003. The petrology of basanite-tephrite inclusions in the Erongo Complex and implications for a plume origin of Cretaceous alkaline complexes in Namibia. Journal of Petrology, 44:93-111.

Available at www.sbgeo.org.br 